\title{
Genetic variability in sorghum (Sorghum bicolor (L.) Moench) genotypes for anthracnose (Colletotrichum sublineolum) resistance, growth and yield related traits at Arba Minch and Derashe districts in southern Ethiopia
}

\author{
Getachew Gudero Mengesha1,2*, Tariku Simion Dojamo ${ }^{1,3}$, Melese Lema Tesema ${ }^{1,3}$, Selamawit \\ Markos Takiso ${ }^{1,3}$ and Dizgo Chencha Cheleko ${ }^{1,4}$
}

\author{
${ }^{1}$ Arba Minch Agricultural Research Center (AmARC), SARI, P.O.BOX. 2228, Arba Minch, Ethiopia. \\ ${ }^{2}$ Crop Protection Division, AmARC, SARI, P.O.BOX. 2228, Arba Minch, Ethiopia. \\ ${ }^{3}$ Crop Breeding Division, AmARC, SARI, P.O.BOX. 2228, Arba Minch, Ethiopia. \\ ${ }^{4}$ Technical Assistance, AmARC, SARI, P.O.BOX. 2228, Arba Minch, Ethiopia.
}

*Corresponding author: E-mail: gechnig@gmail.com; Fax and Tel: (+251) 468812001; Mobile: (+251) 913819431.

Copyright (C) 2021 Mengesha et al. This article remains permanently open access under the terms of the Creative Commons Attribution License 4.0, which permits unrestricted use, distribution, and reproduction in any medium, provided the original work is properly cited.

Received 20th February, 2021; Accepted 9th April, 2021

\begin{abstract}
Anthracnose disease caused by Colletotrichum sublineolum is a major constraint that limits the production and productivity of sorghum in Ethiopia as well as in other countries. This study was carried out at Arba Minch and Derashe districts during the 2018 cropping season, March to August. The objective of the study was to identify the host resistance for anthracnose management and estimate the genetic variability in terms of resistance to anthracnose, growth, and yield potentials of sorghum. The treatments used in the study were 14 sorghum genotypes and laid in a randomized complete block design with three replications. The results from this study showed that Arghiti, Dekeba, and 76TI\#23 were found resistant, while Kolamulato-W, Konso-R, Gambella, and Seredo were highly susceptible to anthracnose. The lowest $(0.25$ $\left.\mathrm{t} \mathrm{ha}^{-1}\right)$ grain yield was recorded from all landraces, whereas the highest $\left(3.22 \mathrm{t} \mathrm{ha}^{-1}\right)$ grain yield was obtained from the genotype Melkam. The high phenotypic and genotypic variances were figured out for the study parameters, while the environmental variance was lower than the genotypic and phenotypic variances. Low to high genotypic (21.40 to $57.94 \%)$ and phenotypic (22.66 to $95.21 \%$ ) coefficients of variations were computed for the study parameters. The high heritability of 59.30 to $99.63 \%$ and the genetic advance in percent means of 20.21 to $63.10 \%$ were calculated for the study parameters. The disease parameters, like disease severity and area under disease progress curve (AUDPC) $(r g=0.725)$, showed a strong and positive association of genotypic coefficients correlations. Also, strong and negative genotypic coefficients of correlations were observed between the disease and traits studied, like AUDPC and grain yield $(\mathrm{rg}=-$ 0.561). The dendrogram of the sorghum genotypes using the Unweighted Pair-Group Method with Arithmetic means analysis and Euclidean distances separated the genotypes into three clusters. The result from this study revealed that the sorghum genotypes noticeably varied in resistance to anthracnose as well as growth and yield potential. Therefore, sorghum producers could beneficially produce resistant, moderately resistant, and high-yielding genotypes with minimum integrated management efforts against the anthracnose. Moreover, the genetic variability and the high heritability together with, and the high genetic gain of the characters, suggest the potential of bettering the genotype for disease resistance and high yield potential through selection.
\end{abstract}

Keywords: Anthracnose, genotypic and phenotypic coefficients of variation, genotypic coefficients correlations, heritability, host resistance, sorghum genotypes. 


\section{INTRODUCTION}

Sorghum (Sorghum bicolor (L.) Moench) is one of the most important cereal crops of the arid and semi-arid environments of the world (Muhammad et al., 2017; Seyoum et al., 2019). It is tolerant to drought-prone than other crops where other crops can no/little survive (Adugna, 2007; Gudu et al., 2013; Seyoum et al., 2019). Globally, sorghum is ranked the 5th cereal crop in terms of area and production after wheat, rice, maize, and barley (FAO et al., 2018; USDA, 2018). In Ethiopia, sorghum is the major staple crop for food and nutrition security, where food security is a key priority for millions of people in arid regions of the country. Despite its importance, the production of sorghum was limited by various biotic and abiotic factors in Ethiopia. Due to this, the national average productivity of sorghum is lower, $2.53 \mathrm{t} \mathrm{ha}^{-1}$ (CSA, 2017), as compared to the world's productivity, $5.88 \mathrm{t} \mathrm{ha}^{-1}$ (USDA, 2018). The average productivity of sorghum in southern Ethiopia $\left(2.23 \mathrm{t} \mathrm{ha}^{-1}\right)$ and particularly in the study areas, Arba Minch and Derashe, the productivity $\left(1.54 \mathrm{t} \mathrm{ha}^{-1}\right)$ is far below as compared to the national average yield, 2.53 $\mathrm{t} \mathrm{ha}^{-1}$ (CSA, 2017).

Among the biotic factors, anthracnose (Colletotrichum sublineolum) is one of the most destructive fungal diseases and the causative agent for low sorghum production (Ali and Warren, 1992; Casela et al., 1997; Thakur and Mathur, 2000). The disease has been reported in many sorghum-producing countries of the world (Tarr, 1962; Ngugi et al., 2000; Hess et al., 2002). In Ethiopia, anthracnose is a prevalent disease all over sorghumproducing areas, particularly in the low and mid-land areas of the country (Chala et al., 2010; Binyam et al., 2016; Girmay et al., 2019). The occurrence of the disease year after year caused significant yield losses in the country. Under favorable conditions, the disease caused yield losses of 50\% (Thakur and Mathur, 2000; Tesso et al., 2012). Yield losses of $100 \%$ had been recorded in highly susceptible sorghum genotypes (Erpelding and Wang, 2007). Besides, uncertainties resulting from climate change and the capability of the pathogen to change rapidly itself and overwhelmed the genotypes' resistance genes were the major challenges in the crop production systems (Chakraborty, 2013; André et al., 2018). Hence, cultivating crop look-alike sorghum with high drought tolerant in connection with high yielder and disease resistance is indispensable. This hints the development of management strategy for anthracnose should considering alone or in combinations of the aforementioned factors in the breeding program of sorghum.

Anthracnose management was not common in Arba Minch and Derashe areas. The areas are hot spot for anthracnose epidemics and in Ethiopia as well. However, to manage the disease, several management options, including cultural procedures, use of resistance varieties, and fungicide application, are available, and efforts have been made worldwide (Casela et al., 1997; Bekele, 2006). The use of resistant variety is the most important management approach as compared to the use of fungicide only in increasing the yield of the crop since growing resistant varieties are the most efficient, economically profitable, and environmentally safe approaches (Green et al., 1990; Agrios, 2005; Erpelding, 2010). However, the long-term durability of the resistant varieties is hampered by variation in virulence within the pathogen population (Ali and Warren, 1987; Marley et al., 2001; Valério et al., 2005). Therefore, the development of resistance variety should consider also the variability of the pathogen in the breeding program.

For the last four decades, more than 50 sorghum varieties have been released by the research systems in Ethiopia. However, a number of sorghum varieties have been turned to susceptible anthracnose and have been moved out of the production systems. Nevertheless, there is evidence that they may be useful when combined with other sources of resistance genes of desirable traits (Erpelding and Wang, 2007; Erpelding, 2010). The released varieties are only depicted as either resistant or moderately resistant or acceptable to disease defense or tolerant at the time of release, issued by the Ministry of Agriculture, Ethiopia. The reasons might be the sorghum varieties were tested for the different agro-ecology or drought-tolerant with high yielder than disease reaction that released by the different research centers at different times in the country. Also, the sorghum varieties may not show differential resistance what they hold the different resistance genes, which confab resistance as a lack of virulent races and favorable environments to the pathogen development. Otherwise, there might be a race variability of the pathogen as these races have been dispersed worldwide (Ali and Warren, 1987; Marley et al., 2001; Valério et al., 2005).

Moreover, most of the released sorghum varieties may not be known for possessing the resistance genes for either vertical or horizontal resistance to anthracnose. Knowledge of patterns of diversity of genetic material against the pathogen may be of great interest and is a key component in crop improvement and breeding programs. The extent of variability is measured by the genotypic and phenotypic coefficient of variation, which provides information about the relative amount of variation in different characters. Continuous improvement of sorghum is imperative for the increased competition for the crop. Hence, the clustering of functional genes for quantitative and qualitative resistance to the different pathogens hints their phylogeny from common descendants by local gene duplication, succeeded by functional diversification (Pande et al., 1991; Gebhardt and Valkonen, 2001; Valério et al., 2005).

The released sorghum varieties in the country may carry 
different genes for resistance to anthracnose and are expected to have wide genetic variation among them. Fundamental constituents in breeding programs and crop improvement are cognition of the patterns of diversity of the genetic materials. However, genetic variability study with the magnitude of the variation and genetic distance among the released varieties and landraces of sorghum for anthracnose and growth and yield-related traits and the need for identification of host resistance have not been studied in the study areas and the country as well. Also, the need for variability assessment and continuous betterment of the sorghum genotype is urgent for the increased competition for the crop, climate change and change of virulence capability of the pathogen, and defeating the genotypes resistance genes. Thus, the objective of the study was to identify the host resistance for anthracnose management from the evaluated sorghum genotypes; and estimate the genetic variability in terms of resistance to anthracnose, growth, and yield-related potentials under natural epiphytotic conditions.

\section{MATERIALS AND METHODS}

\section{Descriptions of the experimental sites}

Testing of sorghum genotypes for susceptibility to anthracnose in areas where the environmental conditions are favorable for the development of the disease across the environments may be a useful method to determines the effectiveness of the selection process in the resistance breeding programs. As reported by Erpelding and Prom (2006), Erpelding and Wang (2007) and Erpelding (2010), the sorghum genotypes variation for resistance to anthracnose and strongly affected by inherited genotypes and different environments. The experiment was conducted at Arba Minch and Derashe districts in southern Ethiopia during the 2018 cropping season, March to August. The two experimental sites are geographically located at $06^{\circ} 06^{\prime} 841^{\prime \prime} \mathrm{N}$ and $037^{\circ} 35^{\prime} 122^{\prime \prime} \mathrm{E}$ (at Arba Minch) and $05^{\circ} 31^{\prime} 31^{\prime \prime} \mathrm{N}$ and $037^{\circ} 25^{\prime} 46^{\prime \prime} \mathrm{E}$ (at Derashe). These areas have an $80 \mathrm{~km}$ distance between them along the convenient vehicle road. These sites are found at an altitude of 1216 (at Arba Minch) and 1253 (at Derashe) meters above sea level. The sites are also characterized by a bimodal rainfall pattern in the region. The short rainy season is in the months of March and April, and the main rainy season is August and November. Thus, Arba Minch and Derashe receive an average total annual rainfall, and temperatures of the climate of the study areas were 750 $\mathrm{mm}$ and $27.50^{\circ} \mathrm{C}$, and $810 \mathrm{~mm}$ and $25.68^{\circ} \mathrm{C}$, respectively. Details of weather data during the 2018 cropping season were presented in Table 1 (National Meteorological Agency, 2018). Additionally, Arba Minch is characterized by moderately alkaline in $\mathrm{pH}$ with low organic contents $(1.05 \%)$ and black sandy-loam in the soil type. Also, moderately alkaline $\mathrm{pH}$ with high organic content $(8.82 \%)$ and black clay-loam in the soil type are the distinctive features of Derashe (MoANR and EATA, 2016).

\section{Experimental materials}

This experiment was carried out in an open environment to assure the disease occurrence and increase natural infections at the starting of the experiment. The experimental materials consisted of 14 sorghum genotypes. The materials are different in sources and growth and yield potentials and levels of reactions to anthracnose upon their release in a different year and under natural field conditions. The seeds were collected from the Melkasa Agricultural Research Center, Ethiopian Institute of Agricultural Research, and farmers' field. The details of agro-ecological, agronomic characteristics and breeding center of the tested sorghum varieties are presented in Table 2. The varieties Gambella and landraces were used as standard and local checks, respectively. The old released variety (Gambella) and newly released variety (Arghiti) were regarded as holding one and more than one resistant genes, respectively. Thus, the two sorghum varieties, Arghiti and Gambella, were used to compare the other sorghum varieties with the most elderly and most recently released ones.

\section{Experimental design and field administration}

During the study, the experimental field was laid out in a completely randomized block design with three replicates, and the treatments were allotted randomly to experimental plots within a block. A total of 14 treatments were used during the experiment. The field layout was arranged in $14.0 \mathrm{~m}$ width $\times 53.1 \mathrm{~m}$ length. The unit plot size was $3.0 \mathrm{~m}$ width $\times 2.4 \mathrm{~m}$ length. The space between plots and adjacent replications was $1.5 \mathrm{~m}$ and $2.5 \mathrm{~m}$, respectively. The plot comprises of five rows and three harvestable middle rows. The plants and the rows were spaced at 15 $\mathrm{cm}$ and $75 \mathrm{~cm}$, respectively. The sorghum genotypes were planted with the recommended rates of seed $\left(10 \mathrm{~kg} \mathrm{ha}^{-1}\right)$ on 18 March 2018 at both locations. The seeds were drilled along the rows. Each row corresponded with approximately 16 plants.

The susceptible sorghum variety, Gambella, was planted at both ends of the row to be used as inoculum sources for the rest of the plant found within the rows. As a result, each plant in each plot has a chance to receive plenty of inocula under natural distribution. The nutrient management was maintained by NPS blended fertilizer (100 kg ha-1 for both locations) as a basal application at the time of planting and $\mathrm{N}$-fertilizers (100 kg ha-1 for Arba Minch and $50 \mathrm{~kg} \mathrm{ha}^{-1}$ for Drashe) with the split application, one-third of it as a basal application at the time of planting 
Table 1. Monthly mean minimum and maximum temperature and total rainfall at Arba Minch and Derashe in southern Ethiopia during the 2018 cropping season.

\begin{tabular}{|c|c|c|c|c|c|c|c|c|c|c|c|c|c|}
\hline Location & Weather variable & Jan & Feb & Mar & Apr & May & Jun & Jul & Aug & Sep & Oct & Nov & Dec \\
\hline \multirow{4}{*}{ Arba Minch } & Maximum $\left({ }^{\circ} \mathrm{C}\right)$ & 29.84 & 30.7 & 28.66 & 26.75 & 26.42 & 24.78 & 25.52 & 26.84 & 28.68 & 27.86 & 28.62 & 28.94 \\
\hline & Minimum $\left({ }^{\circ} \mathrm{C}\right)$ & 15.81 & 15.85 & 17.94 & 17.34 & 17.86 & 17.04 & 18.44 & 18.26 & 17.73 & 17.95 & 16.75 & 17.35 \\
\hline & Rainfall(mm) & 0.00 & 47.6 & 35.50 & 250.7 & 165.0 & 89.00 & 12.80 & 94.40 & 159.4 & 102.6 & 81.00 & 17.76 \\
\hline & $\mathrm{RH}(\%)$ & 35.84 & 39.32 & 58.77 & 66.12 & 64.13 & 50.56 & 44.12 & 63.35 & 69.11 & 60.34 & 57.45 & 16.34 \\
\hline \multirow{4}{*}{ Derashe } & Maximum $\left({ }^{\circ} \mathrm{C}\right)$ & 26.73 & 25.3 & 26.20 & 25.51 & 26.67 & 27.20 & 27.70 & 27.67 & 27.67 & 26.60 & 26.44 & 26.93 \\
\hline & Minimum $\left({ }^{\circ} \mathrm{C}\right)$ & 13.4 & 12.59 & 13.35 & 13.28 & 13.35 & 12.92 & 13.15 & 13.02 & 13.25 & 12.49 & 12.38 & 13.01 \\
\hline & Rainfall (mm) & 37.0 & 28.00 & 48.80 & 204.0 & 170.0 & 164.4 & 85.00 & 96.0 & 96.0 & 319.6 & 186.8 & 32.60 \\
\hline & $\mathrm{RH}(\%)$ & 36.05 & 35.17 & 50.25 & 60.44 & 59.04 & 46.17 & 36.15 & 48.35 & 56.14 & 48.08 & 37.67 & 30.11 \\
\hline
\end{tabular}

Source: The meteorological data were obtained from National Meteorological Agency at Hawassa Branch in the year of 2018 . $\mathrm{RH}=\mathrm{Relative}$ humidity

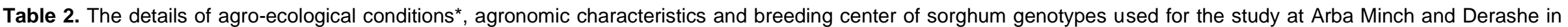
southern Ethiopia during the 2018 cropping season.

\begin{tabular}{|c|c|c|c|c|c|c|c|}
\hline \multirow{2}{*}{$\begin{array}{l}\text { Sorghum } \\
\text { genotypes }\end{array}$} & \multirow{2}{*}{$\begin{array}{l}\text { Accession } \\
\text { code/pedigree }\end{array}$} & \multirow{2}{*}{ Year of release } & \multirow{2}{*}{ Releasing center } & \multirow{2}{*}{ Flowering dates } & \multirow{2}{*}{ Maturity date } & \multicolumn{2}{|c|}{ Productivity $\mathrm{t} \mathrm{ha}^{-1}$} \\
\hline & & & & & & Research & Farmer \\
\hline Gambella & Gambella1107 & 1976 & MARC/EIAR & $80-90$ & $150-200$ & $3.0-5.0$ & - \\
\hline 76TI\#23 & $954062 \times 73 p p 9$ & 1979 & MARC/EIAR & $60-70$ & $90-120$ & $2.5-4.5$ & - \\
\hline Seredo & Seredo & 1986 & MARC/EIAR & $60-70$ & $90-120$ & $3.0-5.0$ & - \\
\hline Meko 1 & M36121 & 1997 & MARC/EIAR & $61-92$ & $120-130$ & $2.2-3.3$ & 1.7 \\
\hline Gobiye & P9410 & 2000 & MARC/EIAR & 83 & $100-120$ & $1.9-2.7$ & - \\
\hline Teshale & 3443-2-OP & 2002 & MARC/EIAR & $65-76$ & $100-120$ & $2.6-5.2$ & - \\
\hline Melkam & WSV387 & 2009 & MARC/EIAR & $76-82$ & 118 & $3.7-5.8$ & $35-43$ \\
\hline Dekeba & ICSR24004 & 2012 & MARC/EIAR & 75 & 119 & $3.7-4.5$ & $26-37$ \\
\hline Arghiti & WSV387/P9403 & 2016 & MARC/EIAR & 79 & 125 & 3.78 & - \\
\hline Landraces & - & - & - & $65-75$ & $110-120$ & - & - \\
\hline
\end{tabular}

MARC = Melkassa Agricultural Research Center; EIAR = Ethiopian Institute of Agricultural Research. *The suitable agro-ecology for the sorghum genotypes are dry lowland with an altitude of $<1600 \mathrm{~m}$.a.s.I., the range of temperature of 27 to $32{ }^{\circ} \mathrm{C}$ and annual total rainfall of < $600 \mathrm{~mm}$. [Source: Data were sourced and organized from MoANR (2016) and MoANR and EATA (2018)].

and two-third of it as top dressing application on 35 days after planting. Weeding, earthling up, thinning practices, and regular monitoring were executed to all plots uniformly as per the recommendations suggested by MoANR and EATA (2018) for the two locations. 


\section{Data collection}

\section{Disease monitoring}

The disease monitoring began after 42 (at Derashe) and 46 (at Arba Minch) days after planting once the disease symptoms appeared on the varieties Gambella, Seredo, and landraces. Disease incidence and severity were scored at every 14-day interval and continued until the majority of the genotypes were physiologically matured. A total of six consecutive assessments were executed during the experiment at both locations. The disease incidence (\%) was determined by the rating of diseased plants per total number of plants assessed within the plot in the three central rows.

The disease severity (\%) was rated visually as the percentage of apparently diseased tissue, leaf area affected, from randomly selected 15 pre-tagged plants per plot using 1 to 5 scale designated by Erpelding and Prom (2004) with some modification, the modifications were built in the use of natural infection instead of artificial inoculations, for the genotypes evaluation against anthracnose, where, $1=$ no visible symptoms or presence of chlorotic flecks or infected whorl, 2 = hypersensitive lesions (reddening or red spot on diseased leaves) on infected leaves with no acervuli formation, $3=$ chlorotic lesions on infected leaves with acervuli in the center, $4=$ necrotic lesions with acervuli on infected leaves with elongation and infection spreading to non-infected leaf tissue and $5=$ coalescence of necrotic lesions on infected leaves with abundant acervuli resulting in leaf death and most leaves including the flag leaf. The levels of resistance for the genotypes were rated as $1,2,3,4$, and 5 with highly resistant, resistant, moderately resistant, susceptible, and highly susceptible, respectively. The higher the severity, the more genotype is susceptible, and vice versa. The disease severity grades were changed into percentage severity index (PSI) for the analysis using the formula described by Wheeler (1969) as followed:

PSI $(\%)=\frac{\text { Sum of numerical ratings }}{\text { No. of plants scored } \times \text { maximum score on scale }} \times 100$

From the disease severity data as the PSI values assessed at different days, the area under disease progress curves (AUDPC), which mean the development and accumulation of disease on the whole plant or part of the plant during the epidemic periods, were computed for each plot using the formula designated by Campbell and Madden (1990) as followed:

AUDPC $=\sum_{i=1}^{n-1} 0.5\left(X_{i}+X_{i+1}\right)\left(t_{i-1}-t_{i}\right)$

Where, $\mathrm{n}$ is the total number of disease assessments, $t_{i}$ is the time of the $\mathrm{i}^{\text {th }}$ assessment in days from the first assessment date and $x_{i}$ is the PSI of disease at the $i^{\text {th }}$ assessment. AUDPC was expressed in \%-days because severity $(\mathrm{x})$ is expressed in percent and time (t) in days.

The disease progress rate (DPR) was estimated by the repetitious assessment of the percentage of leaf areas infected by the disease in each plot commencing from disease onset. To determine which regression model was suitable for assessing DPR, logistic, In [(Y/1-Y)] (van der Plank, 1963), and Gompertz, -In [-In (Y)] (Berger, 1981), regression models were compared for the goodness of suitable in the valuation of disease progression from each treatment. The converted data of disease severity were regressed over time (DAT) to decide the regression model. The logistic regression model was selected based on the superior expression as indicated by the higher values of coefficients of determination $\left(R^{2}\right)$ and the lower standard error value. The logistic regression model was then applied to estimate the apparent rate of disease increase ( $r$ ) and the intercept of the curve using the following formula.

$\mathrm{Y}_{t}=\frac{1}{1+\exp ^{-\ln \left[\frac{\mathrm{Yo}}{1-\mathrm{Yo}}\right]+\mathrm{rLt}}}$

Where: $Y_{t}=$ percentage of severity at $t^{\text {th }}$ assessment date; $Y_{0}=$ percentage of initial severity at $t^{\text {th }}$ assessment date; $t_{i}$ $=$ time of the $i^{\text {th }}$ assessment in days from the first assessment date; and $\mathrm{r}_{\mathrm{L}}=$ the rate parameter determines by production of inoculum by infected individuals/lesions per unit area of diseased tissue.

\section{Growth and yield parameters}

The crop parameters consisted of the number of productive plants per plot (NPP), thousand seed weight (TSW) $(\mathrm{g})$, and grain yield (GY) $\left(\mathrm{t} \mathrm{ha} \mathrm{H}^{-1}\right)$ were considered from growth and yield-related parameters. These parameters were assessed from the three central rows of each treatment within the plot. The whole productive plants found within the three central rows of the plot were used for the determination of NPP and GY. The NPP was determined by counting productive tillers within the plot. Thousand seed weight was measured from randomly sampled grains acquired from the total harvested grains of each plot. The harvested GY and TSW were adjusted to $12.50 \%$ moisture content following the procedure designated by Taran et al. (1998).

\section{Data analysis}

Data for disease and yield-related parameters measured were subjected to analysis of variance to determine the treatment effects following the procedure depicted by 
Gomez and Gomez (1984) for RCBD design. The data were analyzed following the procedures of the general linear model of the SAS software version 9.2 (SAS, 2009). Combined data analysis was performed to obtain mean values for the parameters measured across the locations. The mean was separated between treatments using Fisher's protected least significant difference (LSD) at $5 \%$ probability levels. The descriptive statistics for the components of variance (environmental, genotypic, and phenotypic) with their respective coefficients of variation (ECV, GCV, and PCV) were performed for all the disease and yield-related parameters using Microsoft Excel 2010. The genotypic, environmental, and phenotypic variances over the environments were estimated following the procedure suggested by Burton and DeVane (1953). These components of variance were used for the estimation of the environmental, genotypic, and phenotypic coefficients of variation as described by Singh and Chaudhary (1977) as followed.

Environmental variance $\left(\delta^{2} \mathrm{e}\right)=\mathrm{MSe} / r$

Genotypic variance $\left(\delta^{2} \mathrm{~g}\right)=\frac{\mathrm{MSg}-\mathrm{MSge}}{\mathrm{re}}$

Variety $\mathrm{x}$ environmental variance $\left(\delta^{2} \mathrm{ge}\right)=\frac{\text { MSge }- \text { MSe }}{\mathrm{r}}$

Phenotypic variance $\left(\delta^{2} \mathrm{p}\right)$ due to genetic effects $=\delta^{2} \mathrm{~g}+\frac{\delta^{2} \mathrm{~g}}{\mathrm{e}}+\frac{\delta^{2} \mathrm{e}}{\mathrm{re}}$

Environmental coefficients of variation $(E C V-\%)=\frac{\sqrt{\delta^{2} \mathrm{e}}}{\bar{x}} * 100$

Genotypic coefficients of variation $(\mathrm{GCV}-\%)=\frac{\sqrt{\delta^{2} \mathrm{~g}}}{\bar{x}} * 100$

Phenotypic coefficients of variation $(\mathrm{PCV}-\%)=\frac{\sqrt{\delta^{2} \mathrm{p}}}{\bar{x}} * 100$

Where: $\mathrm{MSe}=$ the mean square of error, $\mathrm{MSg}=$ the mean square of genotype, MSge = the mean square of genotype $\mathrm{x}$ environment, $\delta^{2} \mathrm{e}=$ the error variance, $\mathrm{e}=$ the number of environments, $r=$ the number of replications and $\bar{x}=$ the ground mean.

Sivasubramanian and Madhavamenon (1973) suggested that the GCV and PCV can be classified as low $(<10 \%)$, medium (10 - 20\%), and high (> 20\%). Heritability in a broad sense, genetic advance, and genetic advance as a percent of means, were determined for each disease and crop parameters measured based on the method adopted by Allard (1960) and Falconer and Mackay (1996).

Heritability in broad sence $\left(\mathrm{H}^{2} \mathrm{bs}\right)=\frac{\delta^{2} \mathrm{~g}}{\delta^{2} \mathrm{p}} * 100$
Genetic advance $(G A)=\sqrt{\delta^{2} p} * H^{2}$ bs

Genetic advance as a percent of mean $(\%)=\frac{\mathrm{GA}}{\bar{x}} * 100$

Where: $\delta^{2} p=$ the phenotypic variance, $\delta^{2} g=$ the genotypic variance, $\mathrm{H}^{2}$ bs $=$ the heritability in broad sense and $\bar{x}=$ the ground mean.

Heritability in a broad sense was categorized into low (0 to $30 \%)$, moderate $(30.1$ to $60 \%)$, and high (> 60\%) as suggested by Robinson et al. (1949). Also, the GAM categorized as low $=0$ to $10 \%$, moderate $=10$ to $20 \%$, and high $=>20 \%$ (Johnson et al., 1955).

Phenotypic and genotypic coefficients of correlations between the studied parameters were estimated following the procedure suggested by Miller et al. (1958) from the corresponding components of variance. The significance of phenotypic and genotypic correlations was tested following the t-test, $t=r \sqrt{n-2} / \sqrt{1-r^{2}}$, where, $r$ is the coefficient of correlations and $\mathrm{n}$ is the number of observations. The ' $t$ ' table was visited with $n-2$ degree of freedom. The genetic distance of the genotypes was estimated following the Euclidean distance (ED) determined from the eight of the study parameters of the 14 sorghum genotypes after standardization, which means subtracting the average value and dividing it by the standard deviation, as described by Sneath et al. (1975) as follows.

Euclidean distance $_{j k}=\sqrt{\sum_{i=1}^{n}\left(X_{i j}-X_{i k}\right)^{2}}$

Where: $E D$ between genotypes $\mathrm{j}$ and $\mathrm{k} ; \mathrm{x}_{\mathrm{ij}}$ and $\mathrm{x}_{\mathrm{ik}}=$ disease scores, growth and yield related traits mean values of the $\mathrm{ith}^{\text {th }}$ traits for the genotypes $\mathrm{j}$ and $\mathrm{k}$, respectively; and $\mathrm{n}=$ number of traits used to calculate the distance.

Pair-wise Euclidean distance of the genotypes was estimated on the disease scores, growth and yield-related traits taken together, and the subsequent matrices were used to generate dendrogram by Unweighted Pair-Group Method with Arithmetic means (UPGMA) cluster analysis following the PAST (Paleontological Statistics Software Package for education and data analysis) option of version 3.25 (Hammer et al., 2001). Moreover, for each of the genotypes, the average distance was computed by averaging the distance of a particular sorghum genotype over the other 13 genotypes. The computed average distance was used to estimate which sorghum genotype is closest or distant to the other ones. 


\section{RESULTS}

\section{Variance of the studied parameters}

The mean squares of the combined analysis of variance for the environment, genotype, and genotype by environment interactions under study showed the existence of significant differences among the tested sorghum genotypes (Tables 3 ). The disease response and agronomic desirability of the tested genotypes exhibited a significant variation within the environment and genotype by environment interactions. Significant $(p<0.001)$ difference for all the measured parameters was observed under crosswise assessments. The parameters mean ranged from $6.78 \times 10^{-3}$ for DPR to 80.15 for AUDPC, and the genotypes mean squares ranging between $2.16 \times 10^{-4}$ for DPR and 300272.24 AUDPC, and the environment mean squares ranged from $8.28 \times 10^{-4}$ for DPR to 74553.65 for AUDPC. The coefficients of determination $\left(R^{2}\right)$ for disease parameters ranged from 0.78 for DPR to 0.99 for PSlf (116 DAP), whereas it was ranged from 0.83 for GY to 0.93 NPP for growth and yield-related traits. The two environments and the evaluated sorghum genotypes exhibited significant $(p<0.0001)$ differences in all the disease score, growth, and yield-related parameters measured. On the other hand, various levels of significant $(p<0.0001$ to $<0.05)$ differences were ascertained for the genotypes by environment interaction in all the studied parameters (Table 3).

\section{Response of sorghum genotypes for disease development}

The mean disease incidence figured out for each evaluated genotype ranged from 56.67 for Arghiti to $100 \%$ for the two old released varieties, Seredo, Gambella, and the three landraces, Elgo-W, Kolamulato-W, and Konso$\mathrm{R}$, at final dates of assessment (116 DAT). The remaining eight varieties, Melkam, Meko 1, 76TI\#23, Teshale, Gobiye, Dekeba, Rara-W, and Konso-W, mean values were laid variably in the intermediate ranges in the incidence of the disease at similar dates of assessments, 116 DAT (Table 4). The mean disease severity did not exceed $23.50 \%$ on the variety Arghiti but reached up to $98.33,88.89$, and $80 \%$ on the old released varieties of Gambella, Seredo, and the landrace of Konso-R at final dates of assessment, 116 DAT, respectively. The genotype Melkam, Meko 1, 76TI\#23, Teshale, Gobiye, Dekeba (released varieties), and Elgo-W, Kolamulato-W, Rara-W, and Konso-W (the landraces) remained the disease severity in the intermediate arrays for the last dates of assessment, 116 DAT (Table 4).

The mean highest (1217.22\%-day) and the lowest (599.86\%-day) of AUDPC were recorded on the old (Seredo) and recently released (Arghiti) varieties, respectively. The mean AUDPC of the other genotypes of
Melkam, Meko 1, 76TI\#23, Teshale, Gobiye, Dekeba, Gambella, Elgo-W, Kolamulato-W, Rara-W, Konso-W, and Konso- $R$ were laid variably in the intermediate ranges (Table 4). Based on the rated RG, all the tested genotypes exhibited different RG ranging from 2 to 5 . None of the genotypes showed an RG of 1 . The varieties Arghiti, 76TI\#23, and Dekeba were rated less than 2 RG, while the varieties Melkam, Meko 1, Teshale, and Gobiye were rated as the $R G$ of 3 . The highest $R G$ of 4 and 5 has remained for the two oldest released varieties (Seredo and Gambella) and landraces (Elgo-W, Kolamulato-W, RaraW, Konso-W, and Konso-R) understudied (Table 4). The mean DPR was recorded among the genotypes ranged from 0.0009 for 76Tl\#23 and Dekeba to 0.0209 unit day $^{-1}$ for Gambella. The mean highest DPR of 0.0209 unit day $^{-1}$ was recorded on the variety Gambella, which was statistically at parity with the variety Seredo with 0.0179 unit day ${ }^{-1}$. However, no statistically significant differences were observed among the rest of the released varieties as well as landraces (Table 4).

\section{Performance of sorghum genotypes for studied parameters}

The mean performance of the 14 sorghum genotypes tested in the study for growth and yield-related traits and overall agronomic goodness under crosswise assessment are depicted in Table 5. The mean NPP of the genotypes varied from 28.33 to 95.83 , the minimum is for the landrace of Konso-W and the maximum for the released variety of Seredo, but it is statistically at parity with Rara-W. All the mean values of NPP for the genotypes were laid in the intermediate ranges, but no statistically significant variation has existed between the remaining sorghum genotypes (Table 5). The mean TSW ranged from $12.35 \mathrm{~g}$ for Gambella, Elgo-W, Rara-W, and Konso-R to $31.85 \mathrm{~g}$ for Melkam. The other genotypes remained in the intermediate ranges for TSW. However, the mean TSW obtained from the released varieties, except for Gambella, statistically at par with the variety Melkam. Also, the landraces of Kolamulato-W and Konso-W were statistically at par with Gambella, Elgo-W, Rara-W, and Konso-R. The mean highest GY was recorded for the variety Melkam (3.22 $\mathrm{t} \mathrm{ha}^{-1}$ ), while the lowest GY was recorded for the released variety Gambella and the landraces of Elgo-W and Konso-R with $0.25 \mathrm{tha}^{-1}$ of each of them. The highest GY obtained from the variety Melkam was statistically at parity with the GY recorded from the released varieties of Arghiti, Meko 1, 76TI\#23, Teshale, Gobiye, and Dekeba (Table 5).

\section{Determination of host resistance for the tested sorghum genotypes}

The results obtained from the evaluation of disease 
Table 3. Combined analysis of mean square for disease scores and growth and yield related traits of sorghum genotypes tested across the environments during the 2018 cropping season.

\begin{tabular}{|c|c|c|c|c|c|c|c|c|c|}
\hline $\begin{array}{l}\text { Source of } \\
\text { variation }\end{array}$ & DF & PDIf (\%) & $\mathrm{PSI}_{\mathrm{f}}(\%)$ & RG & $\begin{array}{l}\text { AUDPC } \\
\text { (\%-day) }\end{array}$ & $\begin{array}{c}\text { DPR } \\
\text { (unit day }^{-1} \text { ) }\end{array}$ & NPP & TSW (g) & $G Y\left(t h a^{-1}\right)$ \\
\hline Replication & 2 & $5.43^{\text {ns }}$ & $2.12^{\mathrm{ns}}$ & $0.0357^{\mathrm{ns}}$ & $330.96^{\text {ns }}$ & $1.84 \times 10^{-4 \mathrm{~ns}}$ & $69.89^{\text {ns }}$ & $26.64^{\mathrm{ns}}$ & $1.16^{\mathrm{ns}}$ \\
\hline Environment & 1 & $2125.07^{\star \star \star *}$ & $131.25^{\star \star \star \star}$ & $0.1071^{*}$ & $74553.65^{\star \star \star *}$ & $8.28 \times 10^{-4 * \star \star \star}$ & $7581.00^{\star * * *}$ & $1265.14^{* * * *}$ & $43.18^{* \star * *}$ \\
\hline Genotype & 13 & $1991.12^{\star * \star *}$ & $4035.77^{\star * \star *}$ & $7.3745^{\star * * *}$ & $300272.24^{* * * *}$ & $2.16 \times 10^{-4 * * \star *}$ & $2011.20^{\star \star \star \star}$ & $358.56^{\star \star \star *}$ & $8.18^{\star * * *}$ \\
\hline$G \times E$ & 13 & $225.88^{* * \star *}$ & $18.14^{\star \star}$ & $0.0559^{*}$ & $8700.30^{\star \star \star \star}$ & $5.03 \times 10^{-5 *}$ & $561.56^{* * \star *}$ & $95.80^{* * * *}$ & $3.34^{\star \star * \star *}$ \\
\hline Pooled Error & 52 & 14.21 & 5.95 & 0.0238 & 906.19 & $5.47 \times 10^{-5}$ & 51.05 & 18.68 & 0.198 \\
\hline Pooled F-value & & $80.65^{\star * * *}$ & $328.73^{* * *}$ & $150.43^{\star *}$ & $167.21^{* * * *}$ & $7.36^{\star}$ & $29.77^{* * * *}$ & $14.22^{* \star * *}$ & $10.30^{* * * *}$ \\
\hline$S E$ & & 2.13 & 2.76 & 0.1186 & 24.37 & $8.87 \times 10^{-4}$ & 2.51 & 1.09 & 0.18 \\
\hline Mean & & 80.15 & 52.16 & 3.61 & 868.68 & $6.78 \times 10^{-3}$ & 60.93 & 21.76 & 1.55 \\
\hline CV (\%) & & 4.70 & 4.67 & 4.28 & 3.47 & 34.52 & 11.73 & 19.87 & 28.71 \\
\hline $\mathrm{R}^{2}$ & & 0.97 & 0.99 & 0.98 & 0.98 & 0.78 & 0.93 & 0.87 & 0.83 \\
\hline
\end{tabular}

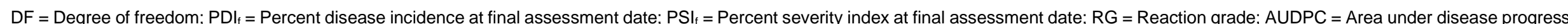

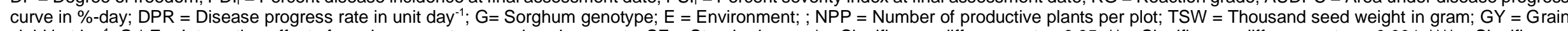

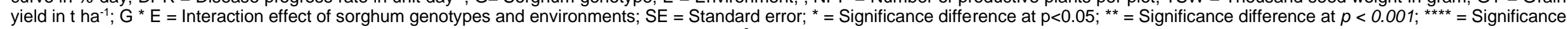
difference at $p<0.0001 ; n s=$ Not significant $(p>0.05) ; C V=$ Coefficients of variation $(\%)$; and $R^{2}=$ Coefficient of determination.

Table 4. Analysis of disease scores estimated for sorghum genotypes under crosswise assessment during the 2018 cropping season.

\begin{tabular}{|c|c|c|c|c|c|}
\hline Sorghum genotypes & PDI $_{f}(\%)$ & PSIf $_{\text {(\%) }}$ & $\mathbf{R G}$ & AUDPC (\%-day) & DPR (Units day ${ }^{-1}$ ) \\
\hline Arghiti & $56.67 d$ & $23.50 \mathrm{~h}$ & $2 e$ & $599.86 j$ & $0.0010 \mathrm{c}$ \\
\hline Melkam & $73.33 \mathrm{bc}$ & $36.11 f$ & $3 c$ & $705.83 \mathrm{~g}$ & $0.0050 \mathrm{bc}$ \\
\hline Meko 1 & $58.33 d$ & $31.39 \mathrm{~g}$ & $3 c$ & $685.42 g-i$ & $0.0034 b c$ \\
\hline 76TI\#23 & $58.75 d$ & $23.61 \mathrm{~h}$ & $2 e$ & $623.19 \mathrm{ij}$ & $0.0009 c$ \\
\hline Gobiye & $65.00 \mathrm{~cd}$ & $30.83 \mathrm{~g}$ & $3 c$ & 693.19gh & $0.0031 b c$ \\
\hline Teshale & $72.08 \mathrm{bc}$ & $41.1 \mathrm{e}$ & $3 c$ & $785.56 f$ & $0.0052 b c$ \\
\hline Dekeba & $62.92 \mathrm{~cd}$ & $24.17 \mathrm{~h}$ & $2 e$ & 632.92h-j & $0.0009 c$ \\
\hline Seredo & $100 \mathrm{a}$ & $88.89 \mathrm{~b}$ & $5 a$ & $1217.22 \mathrm{a}$ & $0.0179 a$ \\
\hline Elgo-W & $100 \mathrm{a}$ & $60.00 \mathrm{~d}$ & $4 \mathrm{~b}$ & $1003.33 c d$ & $0.0063 b c$ \\
\hline Kolamulato-W & $100 \mathrm{a}$ & $76.67 c$ & $5 a$ & $1207.50 \mathrm{a}$ & $0.0091 b c$ \\
\hline Gambella & $100 \mathrm{a}$ & $98.33 a$ & $5 a$ & $1137.50 \mathrm{~b}$ & $0.0209 a$ \\
\hline Rara-W & $80 \mathrm{~b}$ & $56.67 d$ & $4 b$ & $880.83 e$ & $0.0059 b c$ \\
\hline Konso-W & $95.00 \mathrm{a}$ & $60 d$ & $4 b$ & 939.17de & $0.0060 \mathrm{bc}$ \\
\hline Konso-R & $100 a$ & $80 c$ & $5 a$ & $1050 c$ & $0.0090 \mathrm{~b}$ \\
\hline LSD (0.05) & 10.53 & 3.64 & 0.20 & 67.20 & 0.0071 \\
\hline CV (\%) & 4.70 & 4.67 & 4.28 & 3.47 & 34.52 \\
\hline
\end{tabular}

$\mathrm{PDI}_{\mathrm{f}}=$ Percent disease incidence at final assessment date; $P \mathrm{II}_{\mathrm{f}}=$ Percent severity index at final assessment date; RG = Reaction grade; $\mathrm{AUDPC}=$ Area under disease progress curve in \%-day; DPR = Disease progress rate in unit day ${ }^{-1} ; \mathrm{CV}=$ Coefficients of variation (\%); and LSD = Least significant difference at $p<0.05$ probability level. 
Table 5. Analysis of growth and yield related traits of sorghum genotypes as affected by disease pressure under crosswise assessment during the 2018 cropping season.

\begin{tabular}{lccc}
\hline Sorghum genotypes & NPP & TSW (g) & GY (tha ${ }^{-1}$ ) \\
\hline Arghiti & $67.83 \mathrm{~b}$ & $29.29 \mathrm{a}$ & $2.74 \mathrm{ab}$ \\
Melkam & $69.50 \mathrm{~b}$ & $31.85 \mathrm{a}$ & $3.22 \mathrm{a}$ \\
Meko 1 & $61.17 \mathrm{bc}$ & $27.79 \mathrm{a}$ & $2.56 \mathrm{ab}$ \\
76 TI\#23 & $64 \mathrm{bc}$ & $29.07 \mathrm{a}$ & $2.79 \mathrm{ab}$ \\
Gobiye & $63.33 \mathrm{bc}$ & $28.05 \mathrm{a}$ & $2.48 \mathrm{ab}$ \\
Teshale & $56.67 \mathrm{~b}-\mathrm{d}$ & $28.10 \mathrm{a}$ & $2.56 \mathrm{ab}$ \\
Dekeba & $63.67 \mathrm{bc}$ & $25.83 \mathrm{a}$ & $1.85 \mathrm{a}-\mathrm{c}$ \\
Seredo & $95.83 \mathrm{a}$ & $23.84 \mathrm{ab}$ & $1.56 \mathrm{~b}-\mathrm{d}$ \\
Elgo-W & $42 \mathrm{~d}$ & $12.35 \mathrm{c}$ & $0.25 \mathrm{~d}$ \\
Kolamulato-W & $48 \mathrm{~cd}$ & $15.68 \mathrm{bc}$ & $0.51 \mathrm{~cd}$ \\
Gambella & $60 \mathrm{~b}-\mathrm{d}$ & $12.35 \mathrm{c}$ & $0.25 \mathrm{~d}$ \\
Rara-W & $90 \mathrm{a}$ & $12.35 \mathrm{c}$ & $0.27 \mathrm{~d}$ \\
Konso-W & $28.33 \mathrm{e}$ & $15.68 \mathrm{bc}$ & $0.50 \mathrm{~d}$ \\
Konso-R & $39.67 \mathrm{de}$ & $12.35 \mathrm{c}$ & $0.25 \mathrm{~d}$ \\
LSD $(0.05)$ & 18.33 & 8.21 & 1.54 \\
CV $(\%)$ & 11.73 & 19.87 & 28.71 \\
\hline
\end{tabular}

$\mathrm{NPP}=$ Number of productive plants per plot; TSW $=$ Thousand seed weight in gram; GY $=$ Grain yield in $\mathrm{t}^{-1}$; $\mathrm{CV}=\mathrm{Coefficients}$ of variation (\%); and LSD = Least significant difference at $p<0.05$ probability level.

severity for each sorghum genotype at different days of assessment and determinations of host resistance are presented in Table 6 . The genotypes were assembled based on their year of release with 25 years of intervals and disease severity. The computed disease severity for the genotypes at the last date of assessment was ranged from 23.50 for Arghiti, the recently released variety, to $98.33 \%$ for Gambella, the oldest released variety. In the landraces of Elgo-W, Kolamulato-W, Rara-W, Konso-W, and Konso-R, the mean disease severities were ranged from 56.67 for Rara-W to $80 \%$ for Konso-R with the mean value of $66.67 \%$ among them at the final dates of assessment. Also, the mean disease severity of the varieties released from 1976 to 2000, Meko 1, 76TI\#23, Seredo, Gobiye, Gambella, was ranged from 23.67 for 76TI\#23 to $98.33 \%$ for Gamabella with the mean value of $54.61 \%$ among them at final dates of assessment. While the mean disease severity for the varieties released from 2001 to 2016, Arghiti, Melkam, Teshale, and Dekeba, was ranged from 23.50 for Arghiti to 41.11 for Teshale with the mean value of $31.22 \%$ among them at the final dates of assessment (Table 6).

The released varieties were compared with the mean disease severity of the five landraces and the oldest released variety, Gambella, in Ethiopia. The two landraces, Kolamulato-W and Konso-R, and the two released varieties, Gambella and Seredo, were confirmed as highly susceptible genotypes with the disease severity of $76.67,80,98.33$, and $88.89 \%$, respectively. The remaining three landraces of Rara-W, Elgo-W, and Konso-
W, were confirmed as susceptible genotypes with 56.67 , 60 , and $60 \%$ disease severity, respectively. The varieties Gobiye and Meko 1 (released in 1997 and 2000, respectively) and Teshale and Melkam (released in 2002 and 2009, respectively) were evaluated as moderately resistant varieties with the disease severity $31.93,30.83$, 41.11 , and $36.11 \%$, respectively. From the 14 genotypes evaluated, 76TI\#23 (released in 1979), Dekeba (released in 2012), and Arghiti (released in 2016) with the disease severities of $23.61,24.14$, and $23.50 \%$ exhibited resistance genotypes for anthracnose understudied (Table 6). All the tested sorghum genotypes, except for Gambella and Seredo, were decreased disease severity varied from 25.56 to $44.17 \%$ compared with the mean disease severity value $(66.67 \%)$ of the five landraces. All released varieties, including the landraces, showed decreasing disease severity varied from 9.44 to $74.83 \%$ compared with the oldest released variety (Gambella, released in 1976). The released varieties from 1979 onwards, except for Seredo, showed progressive disease severity reductions compared with the oldest released one (Gambella) (Table $6)$.

\section{Genetic variability, heritability and advance in genotypes for studied parameters}

The estimated values of the variance of components, the coefficients of variation for the respective variance, heritability in broad sense, genetic advance and genetic 


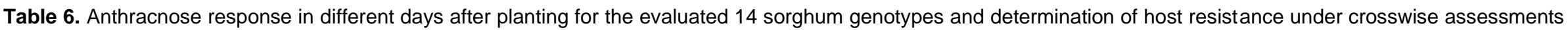
during the 2018 cropping season.

\begin{tabular}{|c|c|c|c|c|c|c|c|c|c|c|}
\hline \multirow{2}{*}{ Sorghum genotypes } & \multirow{2}{*}{$\begin{array}{l}\text { Year of } \\
\text { released }\end{array}$} & \multicolumn{6}{|c|}{ Different days after planting * } & \multicolumn{2}{|c|}{ D/IDSOLOR } & \multirow{2}{*}{$\begin{array}{l}\text { Determination of } \\
\text { host resistance }\end{array}$} \\
\hline & & 44 & 60 & 74 & 88 & 102 & 116 & Landrace & Old released & \\
\hline Rara-W & & 23.33 & 25.00 & 33.33 & 33.33 & 45.00 & 56.67 & - & -41.66 & Susceptible \\
\hline Elgo-W & & 26.67 & 33.33 & 33.33 & 40.00 & 46.67 & 60.00 & - & -38.33 & Susceptible \\
\hline Konso-W & & 25.00 & 28.33 & 35.00 & 35.00 & 46.67 & 60.00 & - & -38.33 & Susceptible \\
\hline Kolamulato-W & & 28.33 & 31.67 & 31.67 & 40.00 & 48.33 & 76.67 & - & -21.66 & Highly Susceptible \\
\hline Konso-R & & 28.33 & 31.67 & 40.00 & 60.00 & 70.00 & 80.00 & - & -18.33 & Highly Susceptible \\
\hline Mean & & 26.33 & 30.00 & 34.67 & 41.67 & 51.33 & 66.67 & & & \\
\hline Gambella & 1976 & 28.33 & 33.33 & 40.00 & 48.06 & 77.22 & 98.33 & 31.66 & 0.00 & Highly Susceptible \\
\hline 76TI\#23 & 1979 & 20.00 & 20.00 & 23.61 & 23.61 & 23.61 & 23.61 & -43.06 & -74.72 & Resistance \\
\hline Seredo & 1989 & 26.67 & 33.89 & 40.00 & 40.00 & 70.00 & 88.89 & 22.22 & -9.44 & Highly Susceptible \\
\hline Meko 1 & 1997 & 20.00 & 20.00 & 25.00 & 27.50 & 30.83 & 31.39 & -35.28 & -66.94 & Moderately resistance \\
\hline Gobiye & 2000 & 20.00 & 20.00 & 26.11 & 28.33 & 29.18 & 30.83 & -35.84 & -67.50 & Moderately resistance \\
\hline Mean (1976-2000) & & 25.00 & 25.44 & 30.94 & 30.50 & 46.17 & 54.61 & & & \\
\hline Teshale & 2002 & 20.00 & 20.00 & 29.72 & 34.44 & 36.11 & 41.11 & -25.56 & -57.22 & Moderately resistance \\
\hline Melkam & 2009 & 20.00 & 20.00 & 23.61 & 29.72 & 35.00 & 36.11 & -30.56 & -62.22 & Moderately resistance \\
\hline Dekeba & 2012 & 20.00 & 20.00 & 24.16 & 24.17 & 24.17 & 24.17 & -42.50 & -74.16 & Resistance \\
\hline Arghiti & 2016 & 20.00 & 20.00 & 21.94 & 22.50 & 22.50 & 23.50 & -43.17 & -74.83 & Resistance \\
\hline Mean (2002-2016) & & 20.00 & 20.00 & 24.86 & 27.71 & 29.45 & 31.22 & & & \\
\hline LSD (5\%) & & 0.86 & 1.18 & 1.95 & 2.20 & 2.95 & 2.82 & & & \\
\hline CV (\%) & & 3.21 & 4.03 & 5.52 & 5.49 & 5.92 & 4.68 & & & \\
\hline $\mathrm{R}^{2}$ & & 0.97 & 0.98 & 0.96 & 0.98 & 0.99 & 0.99 & & & \\
\hline
\end{tabular}

${ }^{*}$ An average of days after planting was considered for disease assessments starting from disease onset to final date of assessment since disease onset was different at the two environments.

advance as a percent of means for studied parameters are depicted in Table 7. A wide range of significant variation was observed for the $\delta^{2} \mathrm{e}$, $\delta^{2} \mathrm{~g}, \delta^{2} \mathrm{ge}, \delta^{2} \mathrm{pg}, \mathrm{ECV}, \mathrm{GCV}, \mathrm{PCV}, \mathrm{H}^{2}$ bs, GA and GAM among the genotypes understudied. Thus, the results of the present study conveyed the existence of considerable variations among the evaluated genotypes for the disease scores, growth and yield-related traits measured. For the disease scores, the $\delta^{2} \mathrm{e}$ was ranged from $1.82 \times 10$ 5 for DPR to 302.06 for AUDPC. The lowest $(2.76 \mathrm{x}$ $\left.10^{-5}\right)$ and the highest (48595.32) of $\delta^{2} \mathrm{~g}$ were computed from DPR and AUDPC, respectively. Similarly, the lowest $\left(1.5 \times 10^{-6}\right)$ and the highest
(2598.04) of $\delta^{2}$ g were calculated from DPR and AUDPC, respectively. While the $\delta^{2}$ pg estimated as $4.17 \times 10^{-5}$ for DPR (lowest) and 49898.40 (highest) for AUDPC during the study. The highest GCV (77.51\%) and PCV $22.66 \%$ ) were estimated from DPR for the three genetic variability study attributes. The lowest ECV was estimated (for all 
Table 7. Estimation of genetic variability components for anthracnose resistance and growth and yield potential on the tested sorghum genotypes under crosswise assessment during the 2018 cropping season.

\begin{tabular}{lcccccccc}
\hline Attributes & PDI & PSl & RG & AUDPC & DPR & NPP & TSW & GY \\
\hline GM & 80.15 & 52.16 & 3.61 & 868.68 & $6.78 \times 10^{-3}$ & 60.93 & 21.76 & 1.55 \\
$\boldsymbol{\delta}^{2} \mathbf{e}$ & 4.71 & 1.98 & 0.01 & 302.06 & $1.82 \times 10^{-5}$ & 17.00 & 6.23 & 0.07 \\
$\boldsymbol{\delta}^{2} \mathbf{g}$ & 294.21 & 669.61 & 1.22 & 48595.32 & $2.76 \times 10^{-5}$ & 241.61 & 43.79 & 0.81 \\
$\boldsymbol{\delta}^{2} \mathbf{g e}$ & 70.59 & 4.06 & 0.01 & 2598.04 & $1.5 \times 10^{-6}$ & 170.18 & 25.71 & 1.05 \\
$\boldsymbol{\delta}^{2} \mathbf{p g}$ & 329.86 & 672.1 & 1.24 & 49898.4 & $4.17 \times 10^{-5}$ & 327.12 & 56.83 & 1.36 \\
ECV (\%) & 0.03 & 0.03 & 0.02 & 0.02 & 0.63 & 0.07 & 0.11 & 0.17 \\
GCV (\%) & 21.40 & 49.61 & 30.59 & 25.38 & 77.51 & 25.51 & 30.41 & 57.94 \\
PCV (\%) & 22.66 & 49.70 & 30.91 & 25.71 & 95.21 & 29.68 & 34.64 & 75.25 \\
H $^{2}$ bs (\%) & 89.19 & 99.63 & 97.98 & 97.39 & 66.28 & 73.86 & 77.06 & 59.30 \\
GA & 1619.91 & 2582.87 & 109.32 & 21754.60 & 0.43 & 1335.85 & 580.93 & 69.16 \\
GAM (\%) & 20.21 & 49.52 & 30.28 & 25.04 & 63.10 & 21.92 & 26.70 & 44.62 \\
\hline
\end{tabular}

$\mathrm{PDI}_{\mathrm{f}}=$ Percent disease incidence at final assessment date; $\mathrm{PSI}+\mathrm{f}=$ Percent severity index at final assessment date; $\mathrm{RG}=\mathrm{Reaction}$ grade; $\mathrm{AUDPC}=$ Area under disease progress curve; DPR = Disease progress rate; NPP = Number of productive plants; TSW = Thousand seed weight; GY = Grain yield; GM $=$ Ground mean; $\delta^{2} \mathrm{e}=$ Environmental variance $; \delta^{2} \mathrm{~g}=$ Genotypic variance; $\delta^{2}$ ge $=$ Genotype by environmental variance; $\delta^{2}$ pg $=$ Phenotypic variance due to genetic effects; $E C V=$ Environmental coefficients of variation; $G C V=$ Genotypic coefficients of variation; $P C V=P h e n o t y p i c$ coefficients of variation; $\mathrm{H}^{2}$ bs = Heritability in broad sense; $\mathrm{GA}=$ Genetic advance; and $\mathrm{GAM}=$ Genetic advance as a percent of means.

disease scores parameters. High $\mathrm{H}^{2}$ bs were estimated for PDI $_{f}(89.19 \%)$, AUDPC (97.39\%), RG (97.98\%), and PSIf $(99.63 \%)$. Likewise, the high GAM (> 20\%) was computed from all disease score parameters (Table 7). The $\delta^{2}$ pg was higher than $\delta^{2}$ ge in all the disease scores understudied. Among these parameters measured, the difference between PCV and GCV was maximal for DPR; however, the PCV and GCV values for the rest of the disease scores exhibited small differences among them even if the PCV was higher than GCV. A greater $\mathrm{H}^{2}$ bs and GAM were observed for disease scores understudied (Table 7).

On the other hand, the results of the current study indicated that the highest (17.0) and the lowest (0.07) of $\delta^{2}$ e were computed for NPP and GY, respectively. The highest (241.61) and the lowest $(0.71)$ of $\delta^{2} \mathrm{~g}$, and highest (170.18) and the lowest (1.05) of $\delta^{2}$ ge were also computed for NPP and GY, respectively. While $\delta^{2}$ pg was estimated as $327.12,56.83$, and 1.36 for NPP, TSW and GY. Higher GCV (57.94) and PCV (75.25) were computed for GY than the other crop traits, NPP, and TSW, respectively. The lowest ECV was estimated for all growth and yield-related attributes. High $\mathrm{H}^{2}$ bs were estimated for NPP (73.86\%) and TSW $(77.06 \%)$, while an intermediate value of $\mathrm{H}^{2}$ bs was estimated for GY (59.30\%). Likewise, the high GAM (> 20\%) was computed for NPP, TSW, and GY (Table 7). Among the crop parameters, TSW exhibited higher $\mathrm{H}^{2}$ bs $(77.06 \%)$ and GAM (44.62\%). Similar to that of disease scores, the $\delta^{2}$ pg was higher than $\delta^{2}$ ge in all the growth and yield-related traits understudied. Likewise, the PCV was higher than the GCV for all the growth and yield related traits studied. The difference between PCV and GCV for GY was maximal as compared to the other traits. Even though the PCV was higher than the GCV for NPP and
TSW, the differences were low in their magnitude. The highest $\mathrm{H}^{2}$ bs was computed for disease scores than growth and yield-related traits. The NPP and TSW received higher values of $\mathrm{H}^{2}$ bs as compared to $\mathrm{GY}$, which was laid in the intermediate ranges of the traits understudied. However, all traits considered for sorghum genotypes showed the highest GAM in the study (Table 7).

\section{Phenotypic and genotypic coefficients of correlations among the studied parameters}

In the current study, genotypic and phenotypic coefficients of correlations were determined to acquire better estimates of the relationships between disease resistance, growth, and yield potential. The genotypic and phenotypic coefficients of correlations for all pairs of eight parameters are presented in Table 8. Among the disease parameters, positive and highly significant $(p<0.0001)$ genetic correlations were observed between $\mathrm{PDI}_{\mathrm{f}}$ and $\mathrm{PSI}_{\mathrm{f}}(\mathrm{rg}=$ 0.548), PDI $\mathrm{f}_{\mathrm{f}}$ and AUDPC ( $\left.\mathrm{rg}=0.548\right), \mathrm{PSI}_{\mathrm{f}}$ and AUDPC ( $\mathrm{rg}$ $=0.725), \mathrm{PSI}_{\mathrm{f}}$ and DPR $(\mathrm{rg}=0.571)$ and AUDPC and DPR $(\mathrm{rg}=0.445)$ (Table 8$)$. The genetic correlations analysis indicated that positive and high correlations were observed between and among mean values of crop parameters (NPP, TSW, and GY). But negative and high correlations were detected between and among mean values of disease and crop parameters. The disease parameters of $\mathrm{PDI}_{f}, \mathrm{PSl}_{\mathrm{f}}$ and AUDPC were highly and negatively $(p<0.0001)$ correlated with NPP $(\mathrm{rg}=-0.744,-0.497$ and 0.534 , respectively), TSW $(\mathrm{rg}=-0.619,-0.467$ and -0.569 , respectively) and $\mathrm{GY}(\mathrm{rg}=-0.652,-0.447$ and -0.561 , respectively). However, the genetic correlations between 
Table 8. Genotypic and phenotypic coefficients of correlations ( $r$ - values) above and below diagonal for disease scores and growth and yield related traits as tested across the environments during the 2018 cropping season.

\begin{tabular}{|c|c|c|c|c|c|c|c|c|}
\hline Attributes & PDlf $_{f}$ & $\mathrm{PSI}_{\mathbf{f}}$ & $\mathbf{R G}$ & AUDPC & DPR & NPT & TSW & GY \\
\hline $\mathrm{PDI}_{f}$ & & $0.548^{* * \star *}$ & $0.203 \mathrm{~ns}$ & $0.548^{\star \star \star \star}$ & $0.182 \mathrm{~ns}$ & $-0.744^{\star * \star *}$ & $-0.619^{\star \star \star *}$ & $-0.652^{\star \star * *}$ \\
\hline $\mathrm{PSI}_{\mathrm{f}}$ & $0.856^{\star * * *}$ & & $0.292^{*}$ & $0.725^{\star \star \star \star}$ & $0.571^{* * * *}$ & $-0.498^{\star * \star *}$ & $-0.467^{\star \star * *}$ & $-0.447^{\star \star \star *}$ \\
\hline$R G$ & $0.850^{* * * *}$ & $0.958^{* * \star *}$ & & $0.277^{\star}$ & $0.045^{\mathrm{ns}}$ & $-0.381^{* *}$ & $-0.200^{n s}$ & $-0.186^{n s}$ \\
\hline AUDPC & $0.889^{* * * *}$ & $0.952^{* \star \star \star}$ & $0.939^{\star \star \star \star}$ & & $0.445^{\star * \star *}$ & $-0.534^{\star * \star *}$ & $-0.569^{\star \star \star *}$ & $-0.561^{\star \star \star \star}$ \\
\hline DPR & $0.547^{\star * * *}$ & $0.699 * * \star *$ & $0.594^{\star * \star *}$ & $0.662^{\star \star \star \star}$ & & $-0.309^{\star \star}$ & $-0.285^{\star}$ & $-0.270^{\star}$ \\
\hline NPP & $0.023^{\text {ns }}$ & $0.003^{\text {ns }}$ & $-0.031^{n s}$ & $0.019^{n s}$ & $0.231^{*}$ & & $0.758^{\star * \star \star}$ & $0.752^{* * * *}$ \\
\hline TSW & $-0.374^{* * *}$ & $-0.530^{* * * *}$ & $-0.561^{* * * *}$ & $-0.448^{* * * *}$ & $-0.144^{\mathrm{ns}}$ & $0.499^{* * * *}$ & & $0.984^{* * * *}$ \\
\hline GY & $-0.299^{* *}$ & $-0.481^{* * * *}$ & $-0.512^{\star * * *}$ & $-0.405^{\star * * *}$ & $-0.117^{n s}$ & $0.510^{\star * \star *}$ & $0.982^{\star * \star *}$ & \\
\hline
\end{tabular}

$\mathrm{PDI}_{\mathrm{f}}=$ Percent disease incidence at final assessment date; $\mathrm{PSI}_{\mathrm{f}}=$ Percent severity index at final assessment date; RG = Reaction grade; AUDPC $=$ Area under disease progress curve; $\mathrm{DPR}=$ Disease progress rate; NPP = Number of productive plants; TSW $=$ Thousand seed weight; GY = Grain yield; ${ }^{*}=$ Correlations significance difference at $p<0.05 ;{ }^{* *}=$ Correlations significance difference at $p<0.01 ;{ }^{* * *}=$ Correlations significance difference at $p<0001 ;{ }^{* * *}=$ Correlations significance difference at $p<0.0001$; and $n s=$ Correlations not significant $(p>0.05)$.

and among the crop parameters were highly significant $(\mathrm{p}<0.0001)$ and positively associated with each other, $\mathrm{rg}=$ 0.758 between NPP and TSW, $r g=0.752$ between NPP and $\mathrm{GY}$, and $\mathrm{rg}=0.984$ between TSW and GY (Table 8 ).

Likewise, highly significant $(p<0.0001)$ and positive phenotypic correlations were observed between and

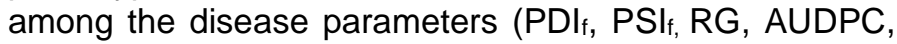
and DPR) with various values of correlation coefficients, $r p$ (Table 8). However, highly significant $(p<0.0001)$ and negative phenotypic correlations of coefficients were observed between and among the crop parameters, except for NPP, which is positively correlated with disease parameters excluding RG, although the associations showed non-significant between them. The correlations analysis exhibited the negative and high phenotypic coefficients of correlations that were noticed between PSI and TSW (rp $=-0.530), R G$ and TSW ( $r p=-0.561)$, and AUDPC and TSW ( $r p=-0.448)$. Also, GY was highly significant $(p<0.0001)$ and negatively correlated with $\mathrm{PSI}_{f}$ $(r p=-0.481), R G(r p=-0.512)$ and AUDPC ( $r p=-0.405)$. However, GY showed positive and highly significantly $(p<0.0001)$ phenotypic correlations with NPP and TSW, but highest with TSW ( $r p=982)$ than NPP $(r p=0.510)$. Thousand seed weight was highly significant and positively correlated with NPP ( $\mathrm{rp}=499)$. In general, phenotypic coefficients of correlations for all parameters were greater than genotypic coefficients of correlations, except for the genotypic coefficients of correlations estimated between NPP and TSW, NPP and GY, and TSW and GY (Table 8).

\section{Genetic distance and clustering of sorghum genotypes}

The results of Euclidian similarity and distance matrix estimated (a measure of genetic distance) among the 14 sorghum genotypes were depicted in Table 9. The ED was ranged from 10.48 (between Meko 1 and Gobiye) to
623.09 (between Seredo and Arghiti) with a mean value of 8.50 and a standard deviation of 4.18 for the evaluated sorghum genotypes. Among the evaluated 14 sorghum genotypes, the genotypes 76TI\#23, Arghiti, and Dekeba were most distant from the two oldest released varieties of Gambella (521.64, 542.02 and 511.15, respectively), and Seredo (599.90, 623.09 and 589.93, respectively) and the landrace of Kolamulato-W (588.54, 612.02 and 578.47, respectively). Melkam (515.54), Meko 1 (537.66), and Gobiye (529.42) varieties were also the most distantly related to the Seredo variety understudied. Conversely, Arghiti (released during 2016) was close to 76Tl\#23 (released during 1979) and Dekeba (released during 2012), and Meko 1 exhibited closeness to Gobiye and Melkam with ED of $<30$. Based on average values of the ED, Teshale (196.90) followed by Rara-W (200.60), Melkam (208.70), Konso-W (209.70), Gobiye (212), and Meko 1 (215.70) were closest to the other genotypes, while Seredo (356.90) and Kolamulato-W (345.80) followed by Gambella (296.10) were distantly related to most the genotypes evaluated (Table 9).

The Euclidean dissimilarity matrix was used to cluster the genotypes following the UPGMA algorithm. The disease scores, growth, and yield-related traits of the 14 sorghum genotypes dendrogram showed that three clusters were made at a dissimilarity coefficient of 5.75 (Figure 1). Each of the three clusters (I, II, and III) was formed at a dissimilarity coefficient of $4.91,3.66$, and 2.68 , respectively. Cluster I was composed of seven genotypes that formed subgroups I and II. All the genotypes found in Cluster I were released varieties, including 76TI\#23, Dekeba, Arghiti, Gobiye, Meko 1, Melkam, and Teshale. Under Cluster I, the genotypes in subgroup I (76TI\#23 and Dekeba) were closely related to each other. In subgroup II, the genotypes Meko 1 and Melkam were closely related to each other, whereas Gobiye and Teshale were distantly related to each other within the group (Figure 1). Interestingly, the genotypes in Cluster I comprised the 


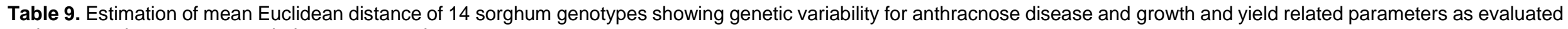
under crosswise assessment during 2018 cropping season.

\begin{tabular}{|c|c|c|c|c|c|c|c|c|c|c|c|c|c|}
\hline $\begin{array}{l}\text { Sorghum } \\
\text { Genotypes }\end{array}$ & $\begin{array}{l}\text { 76TI\#23 } \\
(252.20) \\
\end{array}$ & $\begin{array}{c}\text { Arghiti } \\
(272.30)\end{array}$ & $\begin{array}{l}\text { Dekeba } \\
(245.10)\end{array}$ & $\begin{array}{c}\text { Elgo-W } \\
(224.90) \\
\end{array}$ & $\begin{array}{c}\text { Gambella } \\
(296.10)\end{array}$ & $\begin{array}{l}\text { Gobiye } \\
(212.0)\end{array}$ & $\begin{array}{c}\text { Kolamulato- } \\
\text { W (345.80) }\end{array}$ & $\begin{array}{c}\text { Konso-W } \\
(209.70)\end{array}$ & $\begin{array}{l}\text { Konso- } \\
\text { R (245) }\end{array}$ & $\begin{array}{l}\text { Meko 1 } \\
(215.70) \\
\end{array}$ & $\begin{array}{l}\text { Melkam } \\
(208.70)\end{array}$ & $\begin{array}{l}\text { Rara-W } \\
(200.60) \\
\end{array}$ & $\begin{array}{r}\text { Seredo } \\
(356.90) \\
\end{array}$ \\
\hline Arghiti & 23.76 & & & & & & & & & & & & \\
\hline Dekeba & 11.13 & 34.13 & & & & & & & & & & & \\
\hline Gambella & 521.64 & 545.02 & 511.55 & 140.70 & & & & & & & & & \\
\hline Gobiye & 70.66 & 94.19 & 60.72 & 314.60 & 451.06 & & & & & & & & \\
\hline Kolamulato-W & 588.54 & 612.02 & 578.47 & 204.97 & 74.33 & 517.92 & & & & & & & \\
\hline Konso-R & 433.13 & 456.62 & 422.95 & 51.14 & 90.20 & 362.56 & 157.57 & 115.52 & & & & & \\
\hline Meko 1 & 62.80 & 86.31 & 53.30 & 322.85 & 459.18 & 10.48 & 526.01 & 261.08 & 370.73 & & & & \\
\hline Melkam & 85.07 & 108.18 & 75.10 & 301.55 & 437.50 & 17.61 & 504.74 & 240.67 & 349.21 & 27.39 & & & \\
\hline Rara-W & 262.47 & 285.39 & 252.36 & 133.12 & 262.52 & 192.52 & 330.59 & 90.22 & 176.99 & 200.91 & 178.61 & & \\
\hline Seredo & 599.90 & 623.09 & 589.93 & 222.75 & 88.67 & 529.42 & 50.98 & 289.04 & 174.54 & 537.66 & 515.54 & 338.77 & \\
\hline Teshale (196.90) & 164.02 & 187.60 & 154.03 & 221.43 & 358.03 & 93.45 & 424.64 & 160.53 & 269.36 & 101.65 & 81.01 & 103.67 & 436.98 \\
\hline
\end{tabular}

Numbers in parenthesis indicates mean Euclidean distance of sorghum genotypes obtained by averaging each genotype distance to other 13 genotypes.

oldest (76TI\#23, released during 1979) and relatively the recently released varieties (Arghiti and Dekeba, released during 2012 and 2016, respectively). The Cluster II comprised four landraces (Elgo-W, Konso-W, Konso-R, and Rara$\mathrm{W}$ ), while the two released varieties (Gambella and Seredo) and the one landrace (Kolamulato-W) were grouped under Cluster III. Figure 1 clearly showed the released varieties, except for Gambella and Seredo, under Cluster I was distantly related to the landraces, Cluster III. Similar aspects were observed between Cluster I and Cluster II. Cluster II only included the landraces (Figure 1).

\section{DISCUSSION}

Varietal development is carried out mainly with the utilization of the available genetic variability of the genotypes with the traits of concern (Makanda et al., 2009). The traits of interest are greatly affected by the nature of the genotype variation and the different environmental conditions. Similarly, the capability of the pathogen, anthracnose, is strongly influenced by the nature of the genotype and the different environmental conditions. The resistance variety development via breeding for concerned traits is mainly habituated by the extent and nature of variation and interrelatedness between the genotypes and the pathogen. The ascertained variability in the genotypes resistance to anthracnose (Erpelding, 2010) and good crop traits (Maletsema et al., 2019) is a pooled figure of the genetic, environmental, and pathogen does.

Significant variations among the environment, genotype, and the genotype by environment interactions for anthracnose resistance, growth, and yield-related traits were exhibited by the combined analysis of variance. Analysis of disease parameters indicated that both the oldest (76TI\#23) and recently released varieties (Arghiti and Dekeba) exhibited the lowest PDIf, PSIf, RG, AUDPC, and DPR as compared to the landraces and the two old released varieties (Seredo and Gambella). The inherent variability nature of the genotypes, as well as the favorable environmental conditions, might favor the development of the disease. As reported by Hess et al. (2002), Ngugi et al. (2000) and Erpelding (2010), anthracnose disease is strongly influenced by the response of the genotype and the different environmental conditions, warm temperature and high humid conditions.

On the other hand, all the released varieties, 


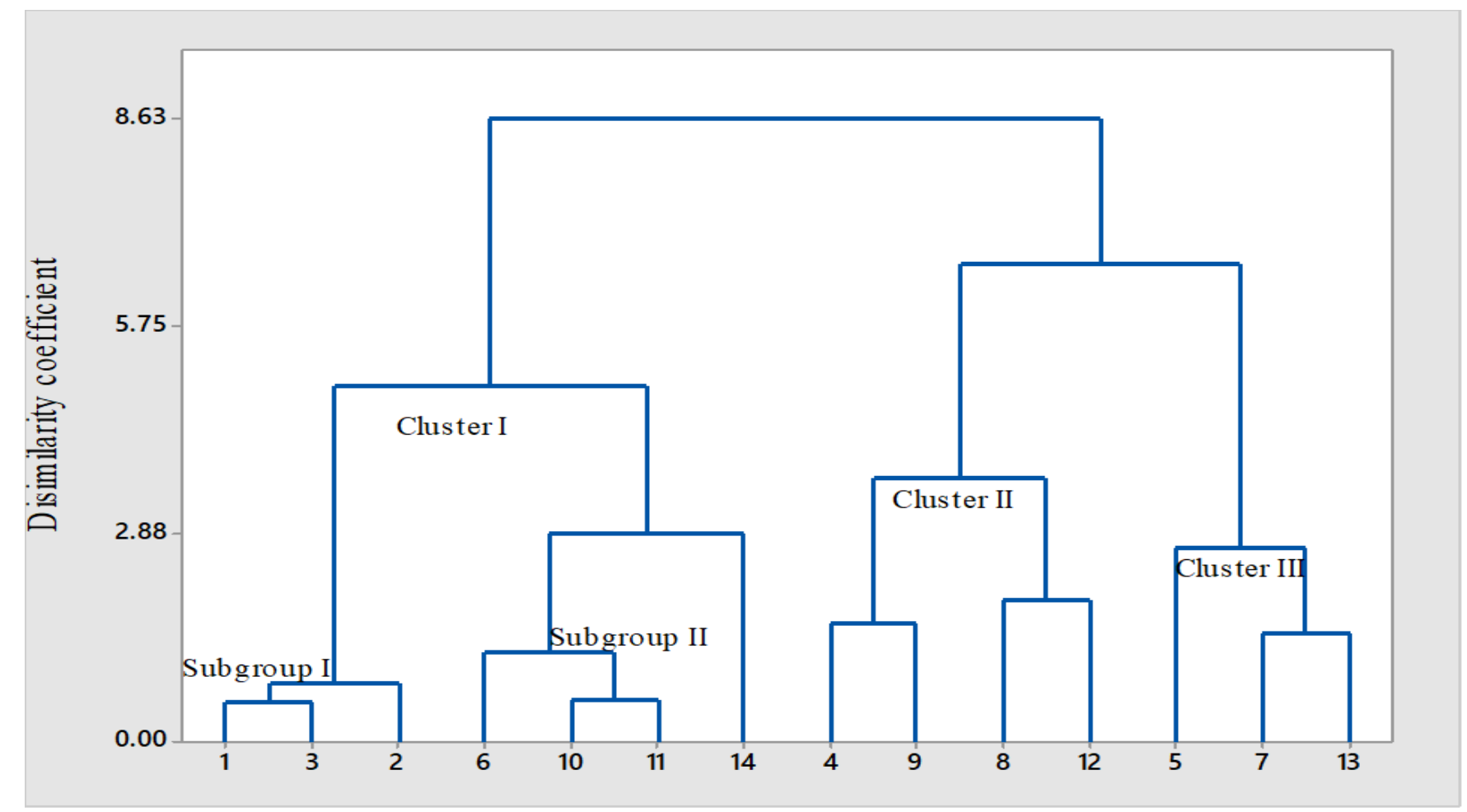

Figure 1. Dendrogram produced by UPGMA clustering method revealing genetic relatedness among 14 sorghum genotypes bases on Euclidian distance analysis of the eight disease scores and growth and yield related traits under crosswise assessment during the 2018 cropping season. Number stands for 1 = 76TI\#23; 2 = Arghiti; $3=$ Dekeba; 4 = Elgo-W; 5 = Gambella; 6 = Gobiye, 7 = Kolamulato-W, 8 = Konso-W; 9 = Konso-R; 10 = Meko 1; 11=Melkam; 12=Rara-W; 13= Seredo; and $14=$ Teshale.

except Seredo and Gambella varieties, showed higher GY response with the cumulative effect of higher NPP and TSW across environments. However, the largest NPP (except for Seredo, Gambella, and Rara-W), TSW, and GY penalty were recorded for the landraces. These variations might probably be associated with the biotic (including anthracnose) and abiotic stress, the low genetic potential for growth and yield-related potentials, the susceptibility of the genotypes, and the environmental conditions during the growing periods. The genotypes which scored the

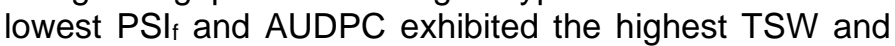
GY. The lowest TSW and GY were recorded for the two old released varieties (Seredo and Gambella) and all the landraces. Shegro et al. (2013), Maletsema et al. (2019), and Seyoum et al. (2019) reported that highly significant variation was observed among the quantitative traits, including NPP, TSW, and GY, as compared to the standard and local checks of sorghum genotypes and the genotypes by environmental interaction.

Genetic variability was noticeable among the tested sorghum genotypes for anthracnose resistance. The two recently released varieties (Arghiti and Dekeba) and the one old variety (76TI\#23) were exhibited resistance to anthracnose. While the four released varieties (Melkam,
Meko 1, Gobiye, and Teshale) and the two released varieties (Seredo and Gambella) and all the landraces showed moderate resistance and susceptible to highly susceptible to anthracnose, respectively. The magnitude of variations in anthracnose reaction was varied due to the nature of genetic makeup and diversity of the evaluated sorghum genotypes and tested environments. Also, this could be ascribed to the fact that recently released varieties, even the old ones, hold different numbers of resistance genes for anthracnose. However, it is difficult to mean all considered as resistant, moderately resistant, or susceptible in the absence of variable races (Erpelding and Prom, 2004; Valério et al., 2005; Erpelding, 2010). This might be due to the strengthened of the recently released varieties over the old ones and the landraces in terms of resistance to anthracnose.

The current study findings were supported by the works that had been done by previous researchers who successfully identified anthracnose resistant sources from the collected sorghum landraces and maintained accessions obtained from different parts of the world, 28 countries including Ethiopia (Erpelding and Prom, 2006; Erpelding and Wang, 2007). A total of 30 accession resistance genes were identified from the tested genotypes from 14 
(including Ethiopia and Mali) out of 28 countries, even though the genotypes were later on defeated by the anthracnose (Erpelding, 2010). Yet, the resistance genes are still useful when aggregated with other sources of genetic materials (Erpelding 2010). In Ethiopia, the released varieties might have either major genes for vertical resistance or minor genes for horizontal resistance against the anthracnose with the existence of unknown resistance genes compared with the old released varieties and the landraces. Now a day, many of the released varieties have become susceptible to anthracnose through time. This might be due to the existence of a wider variability of a given pathogen within the environment (Thomas et al., 1996; Marley et al., 2001; Valério et al., 2005).

In the current study, results clearly showed that genetic variability was apparent in sorghum genotypes. The computed components of variance for the disease, growth, and yield-related parameters measured conveyed that the PCV was higher than the GCV; however, the differences between them were low for most of the parameters studied. This indicated that the reflections of the studied parameters were primarily due to the action of genetic factors with less sensitivity to environmental factors. These results obtained from the present study are in agreement with the reports of Ranjith et al. (2017) and Maletsema et al. (2019) for grow and yield-related traits of sorghum genotypes tested and Wasu (2014) for both disease scores, growth, and yield-related traits studied in potato. The results obtained from the present study revealed that the evaluated sorghum genotypes gave the greater and competent possibility of sorghum improvement when the parameters studied are considered during the selection. This aspect indicates the existence of considerable genetic variability among the released varieties in the country. The estimation of GCV for the disease score parameters was found between ranges of 21.40 (for PDf) to $77.51 \%$ (for DPR). The estimated PCV for the disease score parameters was instituted between ranges of 22.66 (for PDIf) to 95.21 (for DPR). These showed the dignity of a wide range of genetic variability among the evaluated sorghum genotypes.

As stated by Wasu (2014), an assessment of a particular trait for the selection process depends on the genetic and non-genetic factors that influence the expression of phenotypic variations among genotypes. Thus, heritability is a principal component for the selection of characters in crop improvement. The heritability estimation convinced that the existence of a positive response of improving the sorghum genotype through the selection of the target traits. Singh and Chaudhry (1985) suggested that heritability estimates have been authentic when played along with a high estimate of GA. In the present study, a high GA of 21754.60 for DPR and 69.16 to 1335.85 for NPP was computed. High heritability (66.28 for DPR to $99.63 \%$ for $\left.P S I_{f}\right)$ and GAM (20.21 for PSI to $63.10 \%$ DPR) were computed for disease parameters as compared to growth and yield-related traits $\left(\mathrm{H}^{2}\right.$ bs of 59.30 for $\mathrm{GY}$ to $77.06 \%$ for TSW and GAM of 21.92 to $44.62 \%$ for GY). Yet, for all parameters, a high $\mathrm{H}^{2}$ bs with high $\mathrm{GA}$ was observed due to the additive effects of them with less influenced by environments, which suggests more additive gene action (Panse and Sukhatme, 1957) and suggesting that these traits are manageable for selection.

In agreement with the present findings, Shinde et al. (2010) and Sabiel et al. (2016) stated that high heritability together with a high GAM in the genetic variability study of sorghum genotypes was observed and suggested that there is more additive gene action among the tested genotypes, which indicates the studied traits are amenable for selection. However, as suggested by Johnson et al. (1955) and Udeh and Ogbu (2011), only high $\mathrm{H}^{2}$ bs behaves not always be responsible for high estimation of genetic gain to ensure efficient selection for advancement instead of higher $\mathrm{H}^{2}$ bs together with the higher estimation of GCV and GAM. This suggestion indicates that the parameters studied to be efficient for selection in disease resistance and growth and yield potential advancement in sorghum genotypes have to be affirmed with the estimation of higher GCV and GAM. Overall, the high $\mathrm{GCV}, \mathrm{H}^{2}$ bs, GA, and GAM shows the parameters were regulated with additive genetic effect and became heritable in the tested sorghum genotypes.

Significant correlations were observed between and among the disease scores, growth, and yield-related traits at both genotypic and phenotypic levels. The genotypic and phenotypic coefficients of correlations showed the positive and highly significant correlations were observed among the disease parameters. This result indicated that disease parameters were found interrelated to each other. Conversely, highly and negatively correlates disease scores, growth, and yield-related traits were observed among the tested sorghum genotypes, except for NPP, which showed a positive correlation with disease scores excluding RG. The high negative correlations between disease and crop parameters indicate the magnitude to which the disease might affect the growth and yield-related traits of the tested sorghum genotypes. Furthermore, the correlation analysis exhibited the disease pressure caused significant adverse effects on the growth and yield-related traits of sorghum genotypes.

In this regard, the present findings were supported by van der Plank (1963), Campbell and Madden (1990), and Agrios (2005), who reported that plant disease epidemiological parameters were strongly and positively correlated with each other and negatively correlated with growth and yield-related parameters of a crop. On the other hand, a significantly positive correlation was observed among the growth and yield-related traits. Thousand seed weight was highly significant and positively correlated with GY. Various studies reported that correlations among the crop growth and yield components positively correlated between TSW and GY traits (EI-Din et 
al., 2012; Nabin et al., 2013; Maletsema et al., 2019). The present finding suggested that if yield has been evaluated together with disease intensity, the associations between genotypic resistance and yield potential could estimate as a value tight to unity, showing a very high linear relationship between resistance to the disease and yield potential.

Mean ED values among the evaluated sorghum genotypes revealed that the genotypes 76TI\#23, Dekeba, and Arghiti have the minimum distance value as compared to the two oldest released varieties (Seredo and Gambella) and the landraces, indicating that genotypes with low distance were considerably similar, and the genotypes distant to each other revealing the existence of genetic diversity and may give rise to the high heterotic response. The ED among Melkam, Meko 1, Gobiye, and Teshale were closely distanced from one another. A similar report was noticed by Murthy and Arunachalam (1966), Narkhede et al. (2000), and Sudarshan et al. (2013), who reported that the existence of genetic diversity examined as closely related genotypes had a minimum distance to each other and maximum distance had observed between distantly related genotypes. Likewise, the estimated genetic distance enabled the clustering of the sorghum genotypes. The results of this study showed sorghum genotypes with low to high anthracnose resistance were classified in different clusters. The recently and the old one (76TI\#23) released varieties are clustered together since they are closely related to one another. However, these varieties are distantly related to the two oldest released varieties (Seredo and Gambella), and the landraces, the resistant and susceptible genotypes exhibited narrow and wider genetic variations, respectively.

Previous researchers suggested that the clustering of functional genes for the resistance to various pathogens argues the genotypes have come through common ancestors (Gebhardt and Valkonen, 2001; Leister et al., 1996; Valério et al., 2005; Crouch et al., 2006). The two old released varieties (Seredo and Gambella) lost their resistance to anthracnose and demonstrated genetic divergence from the recently released varieties (Arghiti and Dekeba) even with the old variety (76TI\#23). This might be due to the oldest varieties hold the race-specific genes for resistance to anthracnose; however, this might not be true for the recently released varieties. Overall, the present study exhibited that diversity exists among the tested sorghum genotypes for resistance to anthracnose and growth and yield potentials. The genetic variability detected among the tested sorghum genotypes could be helpful in the improvement of sorghum genotypes for resistance to anthracnose and desirable crop traits. The information incurred from this study will assist the breeders in future sorghum breeding programs for anthracnose resistance.

\section{Conclusion}

Significant variations were observed among the sorghum genotypes and the genotype by environment interaction in the response of the disease and the crop parameters measured. The present study results showed that the highest PDIf, PSIf, AUDPC, and DPR with the lowest growth and yield potentials were recorded on the oldest released variety (Gambella) and all the landraces compared with the other released varieties. 76TI\#23, Dekeba, and Arghiti showed resistance to anthracnose than the other genotypes. While Kolamulato-W, Konso-R, Gambella, and Seredo exhibited high susceptibility to anthracnose. Melkam, Meko 1, Gobiye, and Teshale, and Elgo-W, Rara-W, and Konso-W were exhibited moderate resistance and susceptibility to anthracnose, respectively. The high genotypic and phenotypic variances and their respective components of variations were recorded with lowest to highest magnitude for the parameters studied, whereas the environmental variance was far below the genotypic and phenotypic variances and their respective components of variations. The results found in the current study demonstrated that the existence of wide variability for the parameters studied among the tested sorghum genotypes, indicating that selection should lead to an accelerated genetic advancement of disease-resistant and high growth and yield-related traits of the genotypes. The high heritability and GAM were computed for both disease and crop parameters measured. Hence, the results hinted the traits that existed in the genotypes are highly heritable with the engagement of more additive gene action and are suitable for selection. The resistant and moderately resistant genotypes were grouped and found to be the most distant from the other genotypes but are close to each other. These could be used for sorghum production as a management option to manage anthracnose in Ethiopia. The resistance and moderately resistant with high-yielding varieties may also be considered for production with less frequent fungicide application at the time of disease onset. Implementations of integrated disease management are better methods compared with the use of a single management strategy. Because it reduces the primary inoculum sources of the pathogen and less frequent sprays of fungicides to extend the durability of the resistance, increase the efficacy of disease management, reduces environmental side effects and costs of productions. Moreover, the genotypic and phenotypic evaluations are needed to choose suitable resistance genes with high growth and yield-related traits associated with the genetic evaluation methods for resistance breeding. As a result, evaluation of the released varieties and the landraces for resistance to the disease and high yield potential should not be a one-time task since the work needs a repetitive resistance breeding activity.

\section{CONFLICT OF INTEREST}

The authors declare that they have no conflict of interest. 


\section{ACKNOWLEDGEMENTS}

The authors would like to thank Southern Agricultural Research Institute (SARI), Ethiopia, for providing the financial support, and Melkasa Agricultural Research Centre (EIAR), Ethiopia, for providing planting materials. We are also very grateful to the staff of Crop Research Work Process and the drivers of Arba Mnch Agricultural Research Center for their assistance in one way or the other during the study periods. The assistance and efforts made by the staff of Arba Minch Crop Protection Clinic are priceless and beyond word of expression for us.

\section{REFERENCES}

Adugna, A. (2007). The role of introduced sorghum and millets in Ethiopian agriculture. Journal of SAT Agricultural Research, 3(1), 25-31.

Agrios, G. N. (2005). Plant pathology (5th edition). New York: Academic Press-Elsevier. 922 pp.

Ali, M. E. K., \& Warren, H. L. (1987). Physiological races of Colletotrichum graminicola on sorghum. Plant Disease, 71 , 402-404.

Ali, M. E. K., \& Warren, H. L. (1992). Anthracnose of sorghum. pp: 203-208. In: de Milliano, W.A.J., Frederiksen, R. A., \& Bengston, G. D. (eds.). Sorghum and millets diseases: A second world review. International Crops Research Institute for the Semi-Arid Tropics, Patancheru 502 324, A.P., India.

Allard, R.W. (1960). Principles of Plant Breeding. John Willey and Sons, New York. $485 \mathrm{pp}$.

André, C. V., Christian, D. M. C., \& Sheng Y. H. (2018). Plant and pathogen warfare under changing climate conditions. Current Biology, 8(10), 619 - 634.

Bekele, E. (2006). Experience with management of major plant diseases in Ethiopia. In: Bekele, E., Azerefegne, F., \& Abate, T. (eds.). Facilitating the implementation and adoption of Integrated Pest Management (IPM) in Ethiopia. Drylands Coordination Group Proceedings No. 17 Feb 02, 2006. Melkassa Agricultural Research Center, Ethiopia. Pp. 25-34.

Berger, R. D. (1981). Comparison of the Gompertz and Logistic equation to describe plant disease progress. Phytopathology, 71, 716-719.

Binyam, T., Girma, A., \& Fikre, L. (2016). Distribution and importance of sorghum anthracnose (Colletotrichum sublineolum) in Southwestern and Western Ethiopia. Plant Pathology Journal, 15(3), 75-85.

Burton, G. W., \& DeVane, E. H. (1953). Estimating heritability in tall fescue (Festuca arundinacea) from replicated clonal material. Agronomy Journals, 45(10), 478-481.

Campbell, C. L., \& Madden, L. V. (1990). Introduction to plant disease epidemiology (1st edition). John Wiley and Sons, New York. ISBN 0471832367. 532 pp.

Casela, C.R., Pinto, N., Oliveira, E., \& Ferreira, A.S. (1997). Diseases of sorghum. In: Zambolim, L., \& Okay, F. X. R. (eds.). Plant disease control. Minas Gerais, Brazil: Federal University of Vicosa. Pp. 1025-1064.

Central Statistical Agency [CSA] (2017). Agricultural sample survey, 2016/2017. Report on area and production of crops (Private peasant holdings, main season). Central Statistical Agency, Volume 1, No. 584. Addis Ababa, Ethiopia. pp: 10-86.
Chakraborty, S. (2013). Migrate or evolve: options for plant pathogens under climate change. Global Change Biology. 19(7), 1985-2000.

Chala, A., Brurberg, M. B., \& Tronsmo, A. M. (2010). Incidence and severity of sorghum anthracnose in Ethiopia. Plant Pathology Journal, 9(1), 23-30.

Crouch, J. A., Clarke, B. B., \& Hillman, B. I. (2006). Unraveling evolutionary relationships among the divergent lineages of Colletotrichum causing anthracnose disease in turf grass and corn. Phytopathology, 96(1), 46-50.

El-Din, A. A. T., Hessein, E.M., \& Ali, E.A. (2012). Path coefficient and correlation assessment of yield and yield associated traits in sorghum (Sorghum bicolour L.) genotypes. AmericanEurasian Journal of Agricultural \& Environmental Sciences, 12(6), 815-819.

Erpelding, J. E. (2010). Field Assessment of Anthracnose Disease Response for the Sorghum Germplasm Collection from the Mopti Region. American Journal of Agricultural and Biological Sciences, 5(3), 363-369.

Erpelding, J. E., \& Prom, L. K. (2004). Evaluation of Malian sorghum germplasm for resistance against anthracnose. Plant Pathology Journal, 3(2), 65-71.

Erpelding, J. E., \& Prom, L. K. (2006). Variation for anthracnose resistance within the sorghum germplasm collection from Mozambique, Africa. Plant Pathology Journal, 5(1), 28-34.

Erpelding, J. E., \& Wang, M. L. (2007). Response to anthracnose infection for a random selection of sorghum germplasm. Plant Pathology Journal, 6(2), 127-133.

Falconer, D. S., \& Mackay, T. F. C. (1996). Introduction to quantitative genetics, 4th edition. Longman Group Limited Malaidsia. ISBN 0582243025/ ISBN 13: 9780582243026.464 pp.

FAO, IFAD, UNICEF, WFP, \& WHO (2018). The state of food security and nutrition in the world 2018. Building climate resilience for food security and nutrition. Rome, FAO. Licence: $\begin{array}{llll}\text { CC } & \text { BY-NC-SA } & 3.0 & \text { IGO. }\end{array}$ https://creativecommons.org/licenses/by-nc-sa/3.0/igo). ISBN 978-92-5-130571-3. 202 pp.

Gebhardt, C., \& Valkonen, J.P.T. (2001). Organization of genes controlling disease resistance in the potato genome. The Annual Review of Phytopathology, 39(2001), 79-102.

Girmay, A., Alemayehu, C., \& Habtamu, T. (2019). Spatial distribution and association of factors influencing sorghum anthracnose (Colletotrichum sublineolum) epidemics in Eastern Ethiopia. International Journal of pest Management, 67(1), 20-31.

Gomez, K. A., \& Gomez, A. A. (1984). Statistical procedures for agricultural research, 2nd edition. John Wiley and Sons, Inc. New York, Chichester, Brisbane, Toronto and Singapore. 680 pp.

Green, M. B., Le Baron, H. M., \& Moberg, W. K. (1990). Managing resistance to agrochemicals: from fundamental research to practical strategies. American chemical society symposium series number 421. American Chemical Society. USA. $496 \mathrm{pp}$

Gudu, S., Ouma, E. O., Onkware, A. O., Too, E. J., Were, B. A., Ochuodho, J. O., Othieno, C. O., Okalebo, J. R., Agalo, J., \& Maina, S. M. (2013). Preliminary participatory on-farm sorghum variety selection for tolerance to drought, soil acidity and striga in Western Kenya. Maina Moi University, Kenya First Bio-Innovate Regional Scientific Conference United Nations Conference Centre (UNCC-ECA), 25-27 February 2013, 
Addis Ababa, Ethiopia.

Hammer, Ø., Harper, D. A. T., \& Ryan, P. D. (2001). PAST: Paleontological statistics software package for education and data analysis. Palaeontologia Electronica, 4(1), 9p. Retrieved from electronica.org/2001_1/past/issue1_01.htm.

Hess, D. E., Bandyopadhyay, R., \& Sissoko, I. (2002). Pattern analysis of sorghum variety $\times$ environment interaction for leaf, panicle and grain anthracnose in Mali. Plant Disease, 86(12), 1374-1382.

Johnson, H. W., Robinson, H. F., \& Comstock, R. E. (1955). Estimates of genetic and environmental variability in soybeans. Agronomy of Journals, 47(7), 314-318.

Leister, D., Ballvora, A., Salamini, F., \& Gebhardt, C. (1996). A PCR based approach for isolating pathogen resistance genes from potato with potential for wide application in plants. Nature Genetic, 14(4), 421-429.

Makanda, I., Tongoona, P., \& Derera, J. (2009). Quantification of genotypic variability for stem sugar accumulation and associated traits in new sweet sorghum varieties. African Crop Science Conference Proceeding, 9, 391-398.

Maletsema, A. M., Hussein, S., Mark, L., \& Nemera, S. (2019). Genetic variability, heritability and genetic gain for quantitative traits in South African sorghum genotypes. Australian Journal of Crop Science, 13(01), 1-10.

Marley, P. S, Thakur, R. P., \& Ajayi, O. (2001). Variation among foliar Isolates of Colletotrichum sublineolum of sorghum in Nigeria. Field Crops Research, 69(2), 133-142.

Miller, P. A., Williams, J. C., Jr Robinson, H. F., \& Comstock, R. E. (1958). Estimates of genotypic and environmental variances and covariances in upland cotton and their implications in selection 1. Agronomy Journal, 50(3), $126-131$.

Ministry of Agriculture and Natural Resources [MoANR] \& Ethiopian Agricultural Transformation Agency [EATA] (2016). Soil Fertility Status and Fertilizer Recommendation Atlas of the Southern Nations, Nationalities and Peoples' Regional State, Ethiopia. ATA: Ethiopia. Addis Ababa, Ethiopia. Pp. 198-253.

Ministry of Agriculture and Natural Resources [MoANR] \& Ethiopian Agricultural Transformation Agency [EATA]. (2018). Crop production and development package. Amharic Version. Addis Ababa, Ethiopia. 215p.

MoANR (Ministry of Agriculture and Natural Resources) (2016). Plant variety release, protection and seed quality control directorate. Crop variety register. Issue No. 19. Addis Ababa, Ethiopia. Pp. 7-18.

Muhammad, I.K., Muhammad, Z.W.A., Shiraz, A., Ali, N., Amin, B., Muhammad, T. (2017). Performance evaluation of sorghum varieties in pothwar areas of Pakistan. International Journal of Advanced Research, 6(1), 1202-1205.

Murthy, B. R., \& Arunachalam, V. (1966). The nature of genetic divergence in relation to breeding systems in crop plants. Indian Journal of Genetics and Plant Breeding, 26A, 188-198.

Nabin, B., Pahujah, S.K., \& Dharmveer. (2013). Correlation and path coefficient analysis for some DUS traits in forage sorghum [Sorghum bicolor (L.) Moench]. Annals of Biology, 29(2), 127131.

Narkhede, B. N., Akade, J. H., \& Awari, V. R. (2000). Genetic diversity in rabi sorghum local types (Sorghum bicolor (L.) Moench). Journal of Maharashtra agricultural universities, 25(3), 245-248.

Ngugi, H. K., Julian, A. M., King, S. B., \& Peacocke, B. J. (2000). Epidemiology of sorghum anthracnose (Colletotrichum sublineolum) and leaf blight (Exserohilum turcicum) in Kenya. Plant Pathology, 49(1), 129-140.

Ngugi, H. K., King, S. B., Abayo, G. O., \& Reddy, Y. V. R. (2002). Prevalence, incidence and severity of sorghum diseases in Western Kenya. Plant Disease, 86(1), 65-70.

Pande, S., Mughogho, L. K., Bandyopadhyay, R., \& Karunakar, R. I. (1991). Variation in pathogenicity and cultural characteristics of sorghum isolates of Colletotrichum graminicola in India. Plant Disease, 75(8), 778-783.

Panse, V. G., \& Sukhatme, P. V. (1957). Genetics of quantitative characters in relation to plant breeding. Indian Journal of Genetics and Plant Breeding, 17(2), 318-328.

Ranjith, P., Ghorade, R., Kalpande, V., \& Dange, A. (2017). Genetic variability, heritability and genetic advance for grain yield and yield components in sorghum. International Journal of Farm Sciences, 7(2), 90-93.

Robinson, H. F., Comstock, R. E., \& Harvey, P. H. (1949). Estimates of heritability and the degree of dominance in corn. Agronomy Journal, 41(8), 353-359.

Sabiel, S. A., Noureldin, I., Baloch, S. K., Baloch, S. U., \& Bashir, W. (2016). Genetic variability and estimates of heritability in sorghum (Sorghum bicolor L.) genotypes grown in a semiarid zone of Sudan. Archives of Agronomy and Soil Science, 62(1), 139-145.

SAS Institute Inc. (2009). SAS/ Stat Guide for Personal Computers, Version 9.2 ed. SAS Institute Inc., Cary, North Carolina. USA.

Seyoum, A., Gebreyohannes, A., Nega, A., Nida, H., Tadesse, T., Tirfessa, A., \& Bejiga, T. (2019). Performance evaluation of sorghum (Sorghum bicolor (L.) Moench) varieties for grain yield and yield related traits in drought prone areas of Ethiopia. Advance in Crop Science and Technology, 7(2), 439.

Shegro, A., Labuschagne, M. T., Geleta, N., \& van Biljon, A. (2013). Assessment of genetic diversity in sorghum using phenotypic markers. Cereal Research Communications, 41(4), 509-518.

Shinde, D., Biradar, B., Salimath, P., Kamatar, M., Hundekar, A., \& Deshpande, S. (2010). Studies on genetic variability among the derived lines of $B \times B, B \times R$ and $R \times R$ crosses for yield attributing traits in rabi sorghum (Sorghum bicolor (L.) Moench). Electronic Journal of Plant Breeding, 1(4), 695-705.

Singh, R. K., \& Chaudhary, B. D. (1977). Biometrical methods in quantitative genetic analysis. Kalyani Publishers, New Delhi. $318 p$.

Sivasubramanian, S., \& Madhavamenon, M. (1973). Heterosis and inbreeding depression in rice. Madras Agricultural Journal, 60(7), 1139-1144.

Sneath, P. H. A., Sokal, R. R., \& Freeman, W. H. (1975). Numerical Taxonomy: The Principles and Practice of Numerical Classification. Systematic Zoology, 24(2), 263-268.

Sudarshan, P. K., Madhusudhana, R., Suresh, J., \& Ganesh, M. B. (2013). Morphological genetic divergence studies in sorghum (Sorghum bicolor (L.) Moench). International Journal of Tropical Agriculture, 31(3-4), 293-297.

Taran, S. A., Kakar, M. S., \& Bugti, R. A. (1998). Performance of maize varieties/hybrids under irrigated conditions of Balochistan. Sarhad Journal of Agriculture, 14(2), 113-116.

Tarr, S. A. J. (1962). Root and stalk diseases: Red stalk rot, colletotrichum rot, anthracnose, and red leaf spot (pp: 58-73). In: Diseases of sorghum, Sudan grass and brown corn. Commonwealth Mycological Institute, Kew, Surrey, England.

Tesso, T., Perumal, R., Little, C., Adeyanju, A., Radwan, G., 
Prom, L., \& Magill, C. (2012). Sorghum pathology and biotechnology- a fungal disease perspective: Part II Anthracnose, stalk rot, and downy mildew. European Journal of Plant Science and Biotechnology, 6(1), 31-44.

Thakur, R. P., \& Mathur, K. (2000). Anthracnose compendium of sorghum diseases. In: Frederiksen RA, Odvody GN, Eds. St. Paul, MN USA: American Phytopathological Society Press. ISBN: 0890542406. Pp. 10-12.

Thomas, M. D., Sissoko, I., \& Sacko, M. (1996). Development of leaf anthracnose and its effect on yield and grain weight of sorghum in West Africa. Plant Disease, 8, 151-153.

Udeh, I., \& Ogbu, C. (2011). Principal component analysis of body measurements in three strains of broiler chicken. Science World Journal, 6(2),11-14.

United State Department of Agriculture [USDA] (2018). Foreign Agricultural service: World Agricultural Production Global Analysis. In: World agricultural supply and demand report. Circular series WAP 11-18, DC 20250-1051. November 2018. Washington, USA. $31 \mathrm{pp}$.
Valério, H. M., Resende, M. A., Weikert-Oliveira, R. C. B., \& Casela, C. R. (2005). Virulence and molecular diversity in Colletotrichum graminicola from Brazil. Mycopathologia, 159(3), 449-459.

van der Plank, J. E. (1963). Plant diseases: Epidemics and control. Academic Press, London, UK. 349p.

Wasu, M. (2014). Genetic variability in Potato (Solanum tuberosum L.) Genotypes for Late blight [Phytophthora infestans (Mont.) de Bary] Resistance and Yield at Haramaya, Eastern Ethiopia. East African Journal of Sciences, 8(1) 13-28. Wheeler, B. J. (1969). An Introduction to plant diseases. John Wiley and Sons, Inc. Mitton, P. J. 2000. 374 pp. 